\title{
Induction of Distinct Defense-Associated Protein Patterns in Aphanomyces euteiches (Oomycota)-Elicited and -Inoculated Medicago truncatula Cell-Suspension Cultures: A Proteome and Phosphoproteome Approach
}

\author{
Tom Trapphoff, ${ }^{1}$ Clara Beutner, ${ }^{1}$ Karsten Niehaus, ${ }^{1}$ and Frank Colditz ${ }^{2}$ \\ ${ }^{1}$ University of Bielefeld, Department 7, Proteome and Metabolome Research, Universitätsstraße 25, D-33615 Bielefeld, \\ Germany; ${ }^{2}$ Leibniz University of Hannover, Institute for Plant Genetics, Dept. III, Plant Molecular Biology/Plant Proteomics, \\ Herrenhäuser Str. 2, D-30419 Hannover, Germany
}

Submitted 7 October 2008. Accepted 9 December 2008.

\begin{abstract}
A comprehensive proteomic approach was applied to investigate molecular events occurring upon inoculation of Medicago truncatula cell-suspension cultures with the oomycete root pathogen Aphanomyces euteiches. Establishment of an inoculation assay in the cell cultures allowed a direct comparison between proteins induced by elicitation with a crude culture extract of the oomycete and by inoculation with $A$. euteiches zoospores representing the natural infection carrier. Oxidative burst assays revealed responsiveness of the cell cultures for perception of elicitation and inoculation signals. The plant "elicitation proteome" resembles the "inoculation proteome" in early incubation stages and includes proteins induced following initial oxidative burst and defense reactions, but also proteins involved in the antioxidative system. However, approximately 2 days after incubation, the inoculation proteome differs drastically from the proteome of elicited cultures, where a cessation of responses assignable to $A$. euteiches elicitation occurred. The specific protein induction patterns of zoospore-inoculated cells appeared consistent with the protein induction identified in recent studies for an A. euteiches infection in planta and consist of three functional groups: i) pathogenesis-related proteins, ii) proteins associated with secondary phenylpropanoid or phytoalexin metabolism, and, particularly, iii) proteins assigned to carbohydrate metabolism and energy-related cellular processes. Phosphoproteomic analyses revealed consistent and specific activation of these defense-related pathways already at very early timepoints of inoculation, providing evidence that the identified protein profiles are representative for an established $A$. euteiches infection of M. truncatula.
\end{abstract}

The oomycete root pathogen Aphanomyces euteiches is accountable for a severe root rot disease in several legume crop plants, including pea, where it is considered to be the most destructive disease in areas with temperate or humid climate (Gaulin et al. 2007; Hagedorn 1989; Levenfors et al. 2003). The typical process of the disease is characterized by discolored honey-brown lesions at the host root tissue and subsequently appearing symptoms of root rotting accompanied by significant reductions of root mass. For the parasitic interac-

Corresponding author: F. Colditz; Telephone: +49-511-762-3603; Fax: +49-511-762-3608; E-mail: Colditz@genetik.uni-hannover.de tion formed with the model legume Medicago truncatula, functional genomic analyses, mainly proteomic approaches but also an RNA interference (RNA $i$ )-mediated gene-silencing approach on a group of defense-related proteins (PR-10), have been performed in order to characterize the molecular mechanisms underlying host cellular defense responses (Colditz et al. 2004, 2005, 2007; Nyamsuren et al. 2003).

In general, defense responses of plants against infection by invading pathogens are initiated by pathogen recognition via sensitive perception mechanisms. Concerning the molecular biology of plant pathogenesis, this initial process can be mediated either by a gene-for-gene interaction or by association of nonhost-specific microbial signal molecules, termed general elicitors or pathogen-associated molecular patterns (PAMPs) (Nürnberger et al. 2004; Zhang et al. 2000). Cultivar-specific resistance response occurs when a plant possesses a dominant resistance $(R)$ gene and the pathogen expresses the complementary avirulence (AVR) proteins (Hammond-Kosack and Jones 1996). Usually, a so-called hypersensitive response (HR) will be induced: a rapid and localized cell death of the challenged host tissue to inhibit the spread of the pathogen (Dixon and Harrison 1994). By contrast, PAMP-mediated resistance represents a more adaptive defense system that adjusts the responses to the severity of infection and does not involve recombinatory events at the genetic level in general (Tellström et al. 2007). Thus, activation of a relatively vigorous response like the HR is not obligatorily because a variety of other defense responses are possible: induction of an oxidative burst; expression of defenserelated genes and their products such as chitinases, glucanases, and other pathogenesis-related (PR) proteins; restructuring and reinforcement of the plant cell wall; and the production of antimicrobial secondary compounds like isoflavones, phytoalexins, and other phenolic depositions (Felix et al. 1991; HammondKosack and Jones 1996; Peck et al. 2001).

Unlike the products of avirulence genes, general elicitors are expressed by a broad range of microorganisms and usually are indispensable for their biological fitness. Several of these elicitor molecules have been identified and characterized, including the hepta- $\beta$-glucoside elicitor of the oomycete Phytophthora sojae/megasperma (Sharp et al. 1984), chitin derivates from crude cell-wall extracts of higher fungi (Ren and West 1992), yeast invertase (Basse et al. 1992) or yeast extract-derived elicitors (YE), glycoproteins like the Phytophthora CBEL (Gaulin et al. 2006) or even smaller peptide fragments (Pep-13) (Halim et al. 2004), and flagellin (flg22) representing the first isolated 
general elicitor from gram-negative bacteria (Felix et al. 1999). These elicitors have been applied frequently to cultured plant cells for the elucidation of defense responses. Effects of elicitation on primary as well as secondary metabolite accumulation have been characterized in several plant species at the transcript (Batz et al. 1998; Tellström et al. 2007), proteome, and metabolome level (Broeckling et al. 2005; Farag et al. 2008; Felix et al. 1991; Peck et al. 2001).

In addition to proteomic approaches, several investigations have implicated involvement of protein phosphorylation and dephosphorylation in the regulation of elicitor-stimulated defense responses since treatments of plant cells with pathogenderived elicitors revealed rapid changes of the phosphoprotein profiles ("phosphoproteomics") (Dietrich et al. 1990; Felix et al. 1991; Lecourieux-Ouaked et al. 2000; Peck et al. 2001; Viard et al. 1994). By contrast, inhibition of protein phosphorylation results in the cessation of diverse defense-related pathways such as medium alkalization, generation of reactive oxygen species (ROS), induction of defense gene expression, phytoalexin synthesis, and the HR-like cell death (Grosskopf et al. 1990; Suzuki et al. 1995, 1999). Hence, proteins differentially phosphorylated in response to microbial elicitation are very likely components of signal transduction pathways following microbe and elicitor perception.

At this toehold, cell cultures of plants represent an appropriate and convenient medium for applied proteomic studies. A two-dimensional gel electrophoresis (2-DE) approach was car-

A

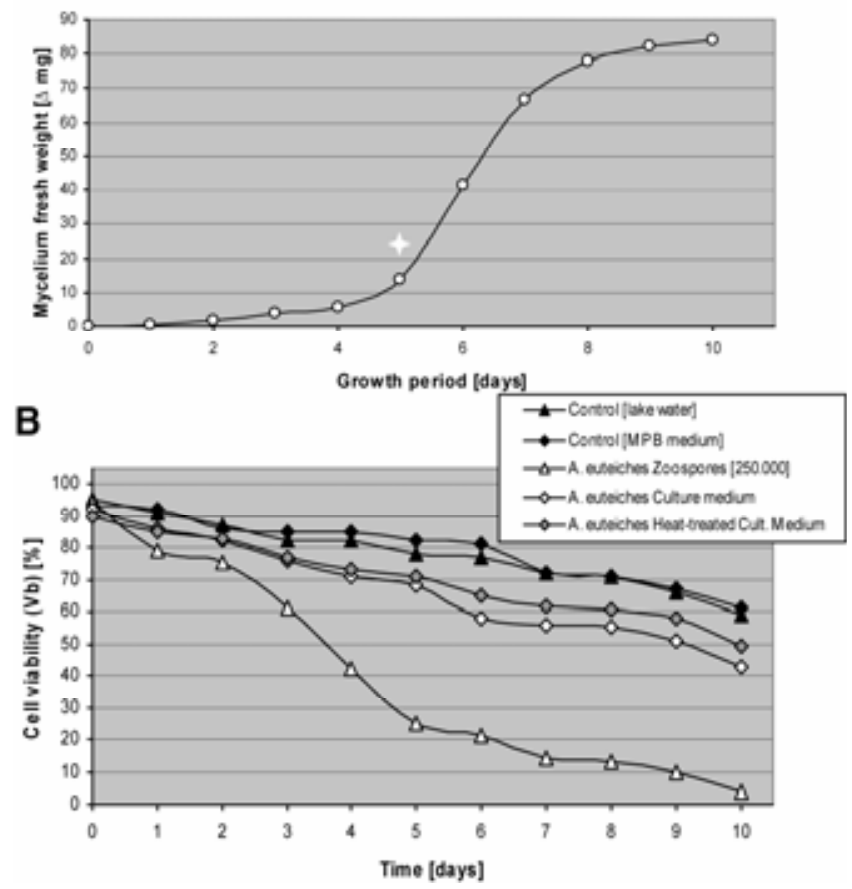

Fig. 1. A, Growth curve of Aphanomyces euteiches in liquid maltose-peptone (MPB) medium and B, Medicago truncatula cell viability ( $\mathrm{Vb}$ ) after A. euteiches inoculation and elicitation. A, Increases in fresh weights ( $\Delta$ $\mathrm{mg}$ ) of A. euteiches mycelia cultured in liquid MPB medium. Fresh weights of 10 independent cultures were measured for 10 days at 24-h intervals and increases to the fresh weights of the initial inoculums were determined. Formation of sporangia was initiated at day 5 of cultivation (marked with an asterisk). B, $M$. truncatula cell viability as determined via the trypan blue (TB) exclusion test. After different treatments, Vb (\%: ratio of viable cells to TB-stained dead cells) was calculated by counting 500 cells. Treatments: A. euteiches zoospore inoculum (white triangles), A. euteiches-filtered culture medium (white diamonds), heat-treated A. euteiches-filtered culture medium (gray diamonds), negative controls (lake water [black triangles] and MPB medium [black diamonds]). The data shown are the results of four biological replicates. ried out to identify upstream phosphorylation pathways in tobacco cells after exposure to the oomycete Phytophthora spp. elicitin cryptogein (Lecourieux-Ouaked et al. 2000). Peck and associates (2001) established a comprehensive phosphoproteome map for Arabidopsis cell cultures in response to bacterial and fungal elicitors. For $M$. truncatula, proteome reference maps for cell suspension cultures have been established (Imin et al. 2004; Lei et al. 2005; Watson et al. 2003).

In the studies presented here, we investigated the parasitic interaction formed between the oomycete root pathogen $\mathrm{A}$. $\mathrm{eu}$ teiches and $M$. truncatula using cell-suspension cultures deriving from M. truncatula A17 root cells. By inoculating them with an A. euteiches zoospore solution on the one hand, which mediates the initial infection processes in the soil, and applying a crude $A$. euteiches elicitor extract obtained from liquid cultures of the oomycete on the other hand, we were able to distinguish between host molecular defense responses of the cells" "inoculation proteome" and the "elicitation proteome". Therefore, we established A. euteiches infection-like stages in the zoospore-inoculated $M$. truncatula cell cultures. Elicitor accumulation was achieved by collecting the culture medium, wherein the pathogen grew during a 10-day period. Proteomics was combined with phosphoproteomic analyses in order to comprehensively characterize infection-specific protein patterns of early defense-related signaling in M. truncatula.

\section{RESULTS}

\section{Experimental design.}

To investigate the pathogenic interaction formed between $M$. truncatula and the oomycete root pathogen A. euteiches, liquid suspension cell cultures generated from $M$. truncatula 'Jemalong A17' roots were exposed independently to two different fractions deriving from $A$. euteiches cultures. i) Cell cultures were inoculated with a zoospore inoculum of $A$. euteiches. ii) Cell cultures were elicited with a crude elicitor obtained from $A$. euteiches culture medium (maltose-peptone [MPB]), wherein the pathogen was cultured over a 10-day-period. At this timepoint, A. euteiches cultures showed a linear growth (days 8 to 10) after a period of marked increases of fresh weights between days 5 and 8 (Fig. 1A). From day 5 on, maturing of zoosporangia is initiated (Fig. 1A, asterisk) but release of zoospores has not been induced (discussed below). At day 10, cultures were filtered to remove A. euteiches mycelia before usage as crude elicitor extract. Additionally, 10-min-boiled culture medium was used for culture elicitation in a separate experiment. To control cultures, lake water that did not contain zoospores (control to i) and pure MPB growth medium in absence of A. euteiches cultures (control to ii) were added to the culture flasks. All fractions tested were applied in equal volumes $(1 \mathrm{ml})$ to the cell cultures.

Cell viability $(\mathrm{Vb})$, as determined using the trypan blue exclusion method, significantly decreased in the cultures treated with the zoospores inoculum compared with the controls (Fig. 1B).

For molecular analyses, biological samples of four independent culture flasks were harvested from both control and $A$. euteiches suspended cell cultures at different timepoints: 0.25 , $1,2,3$, and 4 days post treatments. For the analysis of protein phosphorylation, additional samples were collected at $1.5 \mathrm{~h}$ following treatments. Cells were subsequently extracted from the cell culture medium.

\section{Measurement of ROS \\ in $M$. truncatula cell suspension cultures after inoculation with an $A$. euteiches zoospore suspension and elicitation with $A$. euteiches culture medium.}

For verification of the responsiveness of M. truncatula cell cultures to $A$. euteiches, oxidative burst assays were performed 
and established as a test system to evaluate signal perception deriving from $A$. euteiches cultures $(500 \mu \mathrm{l}$ of lake water containing 125,000 zoospores per culture flask and MPB culture medium in equal volume, respectively). Additionally, heat-treated A. euteiches culture medium was applied to the cell cultures.

All fractions were added independently to discrete cell cultures and a luminol-based chemiluminescence assay was performed to determine the production of hydrogen peroxide $\left(\mathrm{H}_{2} \mathrm{O}_{2}\right)$ during a period of $1 \mathrm{~h}$ after application. Again, four biological replicates were tested. As positive control, the wellestablished plant defense reaction elicitor invertase was added to the cultures, applied in a final concentration of $50 \mu \mathrm{g} \mathrm{ml}^{-1}$. As negative controls, lake water that did not contain zoospores and pure MPB medium in the absence of A. euteiches cultures was used.

Addition of invertase led to the highest measured values for the production of $\mathrm{H}_{2} \mathrm{O}_{2}$ (Fig. 2), with an average maximal concentration of $4.22( \pm 0.23) \mu \mathrm{M}$ at $10 \mathrm{~min}$ after stimulation. Compared with the positive controls, A. euteiches zoospore inoculation and elicitation with culture medium both induced moderate oxidative burst reactions, reaching approximately half of the maxima of the positive controls at $15 \mathrm{~min}$ post treatments; maximal averaged values were $2.27( \pm 0.16) \mu \mathrm{M}$ $\mathrm{H}_{2} \mathrm{O}_{2}$ for the zoospores and $1.88( \pm 0.14) \mu \mathrm{M} \mathrm{H}_{2} \mathrm{O}_{2}$ for $A$. euteiches culture medium, respectively. After attaining the peak of maximal $\mathrm{H}_{2} \mathrm{O}_{2}$ production, values for the oxidative burst decreased continuously but were measurable up to $55 \mathrm{~min}$ after treatment. Interestingly, even the heat-treated medium in which $A$. euteiches had been cultured induced an oxidative burst reaction, reaching $62 \%$ of the maxima of the non-heated culture medium $\left(1.17[ \pm 0.14] \mu \mathrm{M} \mathrm{H}_{2} \mathrm{O}_{2}\right.$ at $\left.15 \mathrm{~min}\right)$. By contrast, lake water and MPB culture medium did not stimulate an increased $\mathrm{H}_{2} \mathrm{O}_{2}$ production in any of the measurements carried out. In addition, application of 3- and 5-day-old culture filtrate of A. euteiches did not result in a measurable $\mathrm{H}_{2} \mathrm{O}_{2}$ production (data not shown).

\section{Microscopic analysis of $A$. euteiches inoculation in $M$. truncatula cell-suspension cultures.}

In order to evaluate germination and growth of $A$. euteiches in the inoculated cell-suspension cultures as well as any association established between both organisms, microscopic studies of the cell cultures at different timepoints after inoculation with the zoospores were performed.

Microscopic pictures from A. euteiches-inoculated M. truncatula cell cultures are shown in Figure 3 . After inoculation, cell cultures were allowed to stand for $1.5 \mathrm{~h}$ in the dark in order to enable an active movement of zoospores toward the plant cells. During this initial period, mobile (biflagellate) zoospores (Fig. 3B and C) released from zoosporangia (Fig. 3A) were detectable in proximity to the plant cells (Fig. 3C). To avoid effects of oxygen deficiency, plant cultures then were carefully transferred on a swiveling table to gently pivot them during another incubation of $3.5 \mathrm{~h}$ in the dark. Within this time period, encysting and germination of cysts was initiated (Fig. 3D). Associations, whether between germinated cysts and plant cells or direct contacts of the germ tube tips to the plant cells, were observed frequently (Fig. 3D and E). At this stage of development, cell cultures were replaced on the culture shaker in the dark. Further microscopic studies ( $>1.5$ days postinoculation [dpi]) revealed that hyphae growth had continued, building on a ramified mesh of absorptive mycelia that encompass the plant cells (Fig. 3D). Thus, an associative cellto-cell network was formed where, especially, aggregates of plant cells were incorporated. From 3 dpi on, plant cells appeared significantly challenged from pathogen inoculation, showing brown discolorations and cell death at 4 to 5 dpi (shown also in Fig. 1B). In contrast, cells of cultures elicited with the crude elicitor exhibited no obvious differences compared with the mock-inoculated cells (shown also in Fig. 1B).

Thus, inoculation of $M$. truncatula cell suspension cultures with A. euteiches zoospores led to infection-like profiles, as are known for plant-pathogenic root-infecting oomycetes (Birch et al. 2006; Gaulin et al. 2007; Kamoun 2006). However, no formation of appressoria and haustoria could be observed in the cells of the suspension cultures.

\section{2-DE analysis of $M$. truncatula cell suspension cultures elicited and inoculated with $A$. euteiches.}

For the monitoring and identification of differences between protein profiles of $A$. euteiches-elicited and -inoculated $M$. truncatula cell suspension cultures and those of control cultures, proteome maps of extracted culture material harvested at the timepoints $0.25,1,2,3$, and 4 days after incubation were produced using two-dimensional (2-D) gel electrophoresis. Therefore, material from four independent biological experiments was taken into account.

2-DE revealed consistent and reproducible resolution of protein patterns comprising approximately 1,000 prominent protein spots per gel in the cell suspension cultures according to the electrophoresis parameters applied (isoelectric focusing [IEF] range of pI 3 to 10 and $\mathrm{M}_{\mathrm{r}}$ range of 10 to $100 \mathrm{kDa}$ ). The proteomic profiling led to the identification of protein patterns appearing consistently at early stages of an A. euteiches inoculation $(0.25$ to $1 \mathrm{dpi})$ that differ from protein patterns appearing consistently at late inoculation stages ( 3 to $4 \mathrm{dpi}$ ). The 2 -dpi timepoint represented a transitional period between early and late inoculation stages, where proteins of both groups could be found induced.

Proteome maps show $M$. truncatula cell-suspension cultures noninoculated and inoculated with A. euteiches zoospores at an early inoculation stage (Fig. 4A, 0.25 dpi) and a late inoculation stage (Fig. 4B, 3 dpi) compared with 2-D maps of cell cultures nonelicited and elicited with $A$. euteiches culture medium at equal timepoints after treatments (Fig. 4C and D, respectively). Evaluation of gels for both early and later inoculation stages revealed independent induction patterns of 19 proteins to be differentially abundant in each time period (Fig. 4A,

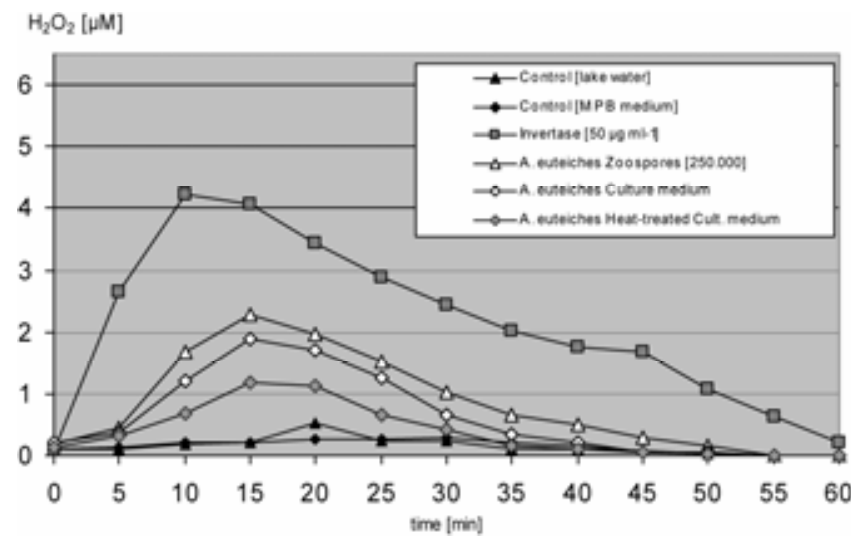

Fig. 2. Induction of oxidative burst in Medicago truncatula suspension-cultured cells after treatment with invertase and two Aphanomyces euteiches fractions. Cells were treated with invertase (gray squares) at $50 \mu \mathrm{g} \mathrm{ml}^{-1}$, with equal volumes of $A$. euteiches zoospores in lake water (125,000 zoospores; white triangles), A. euteiches-filtered culture medium (white diamonds), heat-treated A. euteiches-filtered culture medium (gray diamonds), or lake water representing the negative control to the zoospores treatment (black triangles) and maltose-peptone (MPB) medium as negative control to the $A$. euteiches culture medium (black diamonds), respectively. Production of $\mathrm{H}_{2} \mathrm{O}_{2}$ was determined utilizing the luminal-based chemiluminescence assay. The shown data are the results of four biological replicates. 
spots 1 through 19, and B, spots 20 through 38). Moreover, protein spots were found induced compared with the corresponding protein spots of mock-inoculated control gels.

After elicitation of cells with A. euteiches culture medium, 10 protein spots were found to be differentially induced in gels of initial elicitation stages (Fig. 4C) and 6 proteins for subsequent elicitation stages (Fig. 4D). Interestingly, only three proteins were found to be de novo induced during early elicitation compared with proteins induced after inoculation with $A$. $\mathrm{eu}$ teiches zoospores (Fig. 4C, spots 39 through 41). The same was the case for later elicitation events (Fig. 4D, spots 42 through 44). After elicitation with the heat-treated A. euteiches culture medium, a reduced number of protein spots was found induced: seven protein spots at 0.25 days (spots $3,4,6,10,11,40$, and 41) and four protein spots at 3 days (spots 3, 41, 43, and 44) post treatments (Fig. 4C and D; corresponding spots are labeled with asterisks).

In total, 44 different protein spots were found induced after treatments with $A$. euteiches, whereof 38 proteins were induced after inoculation with the zoospore inoculum while only 16 proteins were induced after elicitation with culture medium, of which 11 proteins also appeared after application of the heattreated elicitor. In gels of mock-inoculated controls, two proteins could be detected showing constantly increased abundances compared with gels of A. euteiches-inoculated cells (Fig. 3, M1 and M2).

\section{Mass spectrometry-based identification of proteins induced after elicitation and inoculation with $A$. euteiches.}

For identification of proteins that were induced after $A$. eute $i$ ches inoculation and elicitor treatment as labeled in Figure 4, tryptic in-gel digestion and matrix-assisted laser desorption ionization time-of-flight (MALDI-TOF) mass spectrometric analyses were carried out. Subsequent alignment of the resulting peptide mass fingerprints (PMF) to the M. truncatula expressed sequence tag (EST) sequence database (Medicago truncatula Gene Index [MtGI]) led to the identification of all 44 proteins that were found induced in $M$. truncatula cell suspension cultures after $A$. euteiches inoculation. By contrast, additional blast analysis of all sequences to the "Aphano DB" EST database (Madoui et al. 2007) resulted in no matches found for any sequence analyzed. Hence, all proteins identified were regarded as being of plant origin.

In Table 1, the identified proteins are listed according to their specific induction, displaying the timepoints of their occurrence protein induction at early stages of $A$. euteiches zoospore inoculation (spots 1 to 19) and protein induction at later inoculation stages (spots 20 to 38) (both stages are shaded dark gray), protein induction at the transitional 2-dpi timepoint (shaded in light gray) of all 38 proteins, additional induction of proteins after A. euteiches elicitor treatment (spots 39 to 44), and protein induction of mock inoculation (M1 and M2).

The identified induction pattern for early stages of A. euteiches inoculation comprises proteins involved in pathogen recognition and initial defense responses, including those related to ion homeostasis, production of ROS, signal transduction, cell wall restructuring, and redox reactions: spot 2 , with sequence similarities to a plasma membrane-type ATPase 9; superoxide dismutase precursor (spot 6); In2-1 protein/glutathione $S$-transferase (GST) (spot 3); phospholipid hydroperoxide glutathione peroxidase (spot 7); two voltage-dependent anion channel porins (VDAC), 1.3 and 1.1 (spots 10 and 11); and a
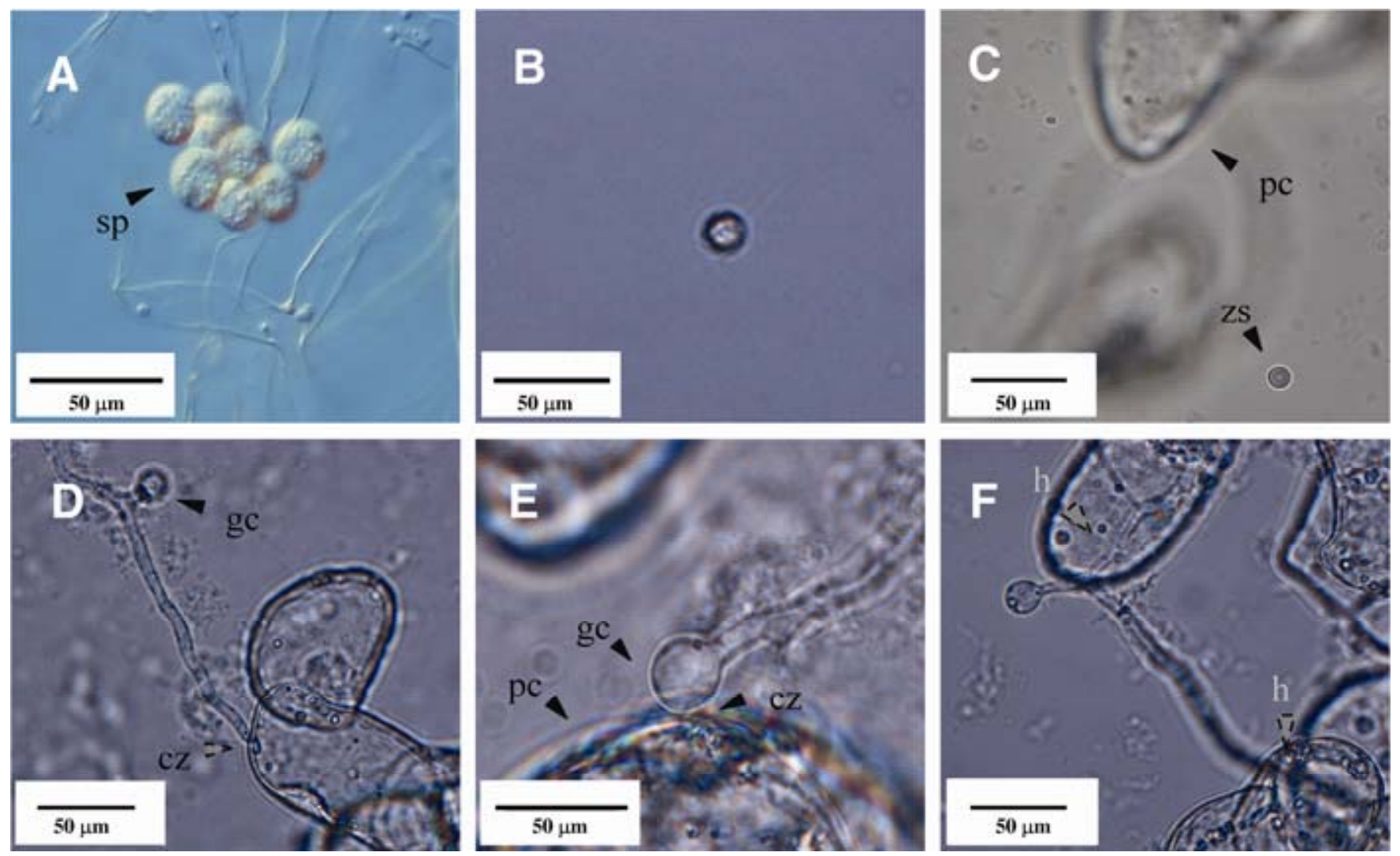

Fig. 3. A through D, Microscopic analyses of Aphanomyces euteiches zoospore-inoculated Medicago truncatula cell cultures. A, A. euteiches zoosporangia (zs). B, Mobile (biflagellate) zoospore (flagella which are easily identified in the microscope are not visible here). C, Zoospore (zs) appearing in proximity of plant cell (pc). D, Germinating cyst (gc) forming a germ tube; contact zone (cz) between germ tube and plant cell. E, Germinating cyst in contact with plant cell. F, Formation of a ramified mesh of absorptive mycelia that encompass the plant cells. A. euteiches hyphae (h) are partially covered by plant cells as marked in gray. 

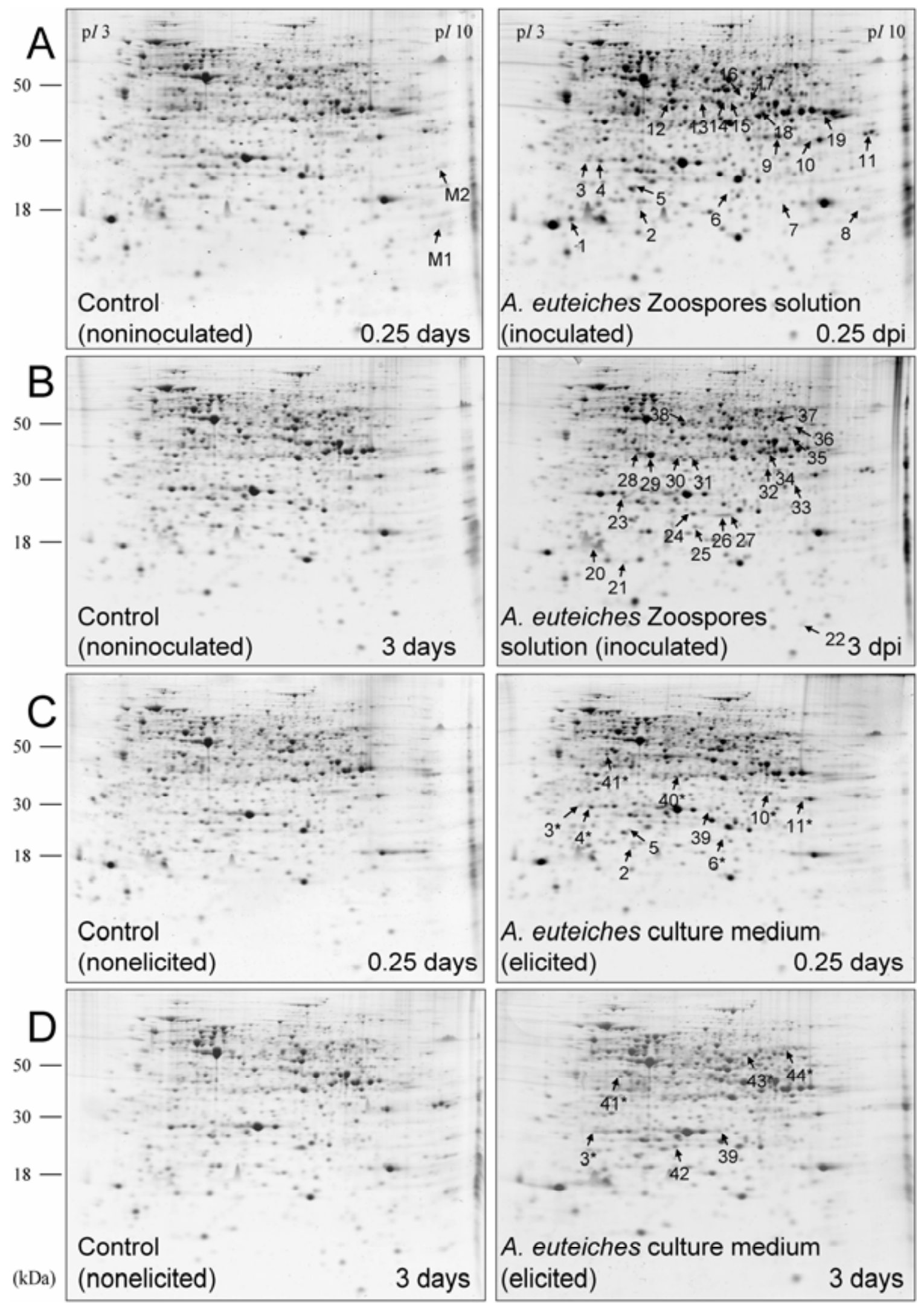

Fig. 4. Proteome maps of Medicago truncatula A17 cell suspension cultures, mock inoculated (controls) and incubated with Aphanomyces euteiches zoospores and culture medium. Gels for $\mathbf{A}$ and $\mathbf{C}$, an early timepoint ( 0.25 days) and $\mathbf{B}$ and $\mathbf{D}$, a late timepoint ( 3 days) post treatments are shown. $\mathbf{A}$ and $\mathbf{B}$, Two-dimensional (2-D) gels of cell cultures inoculated with lake water and with A. euteiches zoospores at A, 0.25 and $\mathbf{B}, 3$ days postinoculation (dpi). Differentially induced proteins that were identified by mass spectrometry are numbered 1 to 38, M1, and M2. C and D, 2-D gels of cell cultures elicited with maltose-peptone (MPB) culture medium and A. euteiches MPB cultures (filtered) at $\mathbf{C}, 0.25$ and $\mathbf{D}, 3$ dpi. Differentially induced and identified proteins are numbered. Protein spots labeled with asterisks were found induced after treatment with heat-treated A. euteiches culture medium. All gels are stained with Coomassie Brilliant Blue. 
Table 1. Analysis of the inoculation proteome and elicitation proteome of Medicago truncatula cell-suspension cultures inoculated with Aphanomyces euteiches ( 0.25 to 4 days; $1.5 \mathrm{~h}$ ) with protein identification for induced proteins after early and late A. euteiches cell inoculation stages, cell elicitation, and mock inoculation (1-44, M1, and M2)

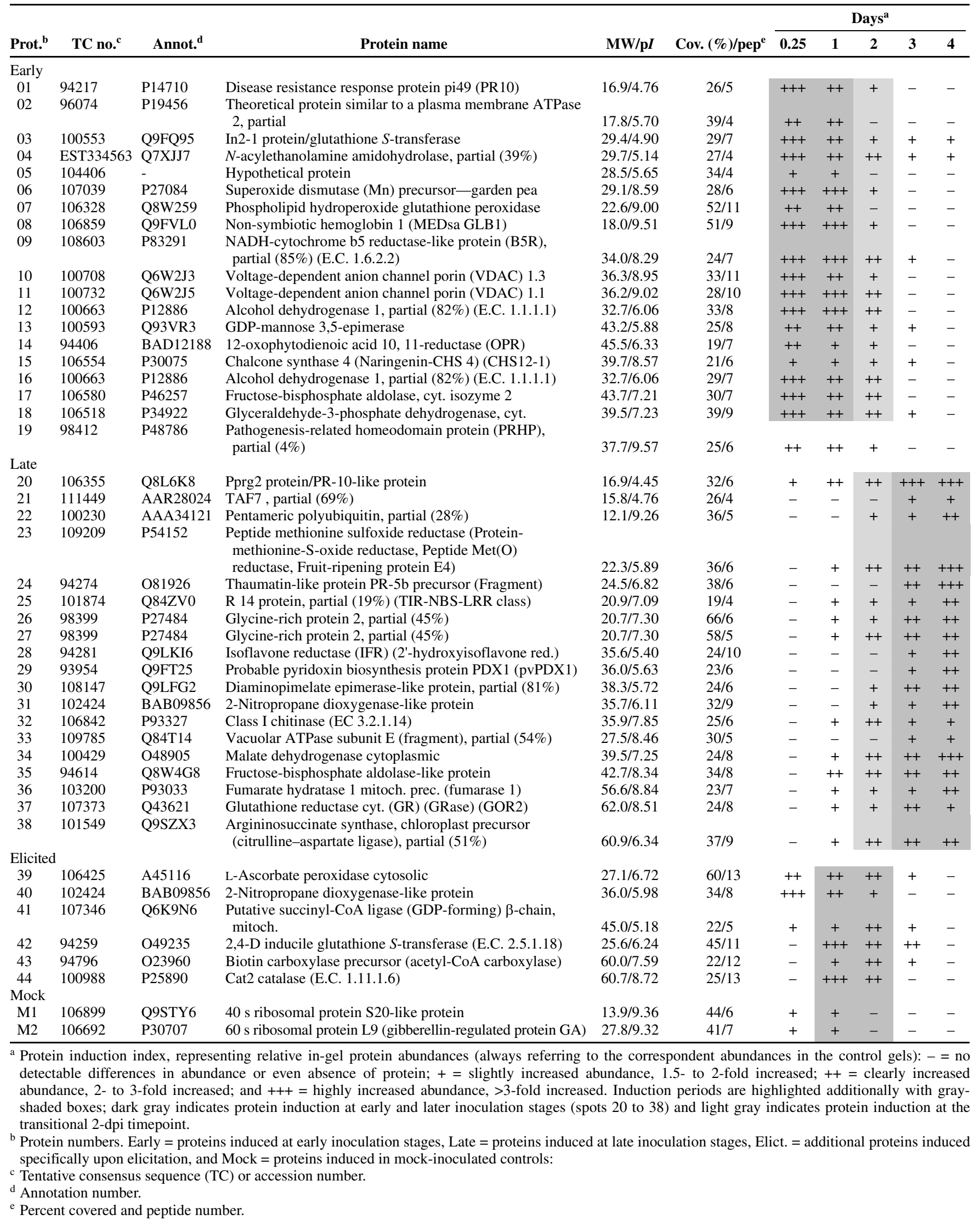


12-oxophytodienoicacid 10-11 reductase (OPR) (spot 14) of the octadecanoid pathway. Additionally, PR protein induction (spots 1, 8, and 19) was initiated as well as the induction of proteins associated with secondary phenylpropanoid metabolism involved in phytoalexins synthesis (spots 9 and 15).

Among the proteins induced at later A. euteiches inoculation stages, PR proteins became predominant: a Pprg 2/PR10-like protein (spot 20), a thaumatin-like protein PR-5b precursor (spot 24), and a class I chitinase (spot 32). Interestingly, with protein spot 25 (R14 protein), a Toll/Interleukin1 receptor nucleotide-binding site leucine-rich repeat (TIR-NBS-LRR)-type resistance $\left(\mathrm{R}^{-}\right)$protein could be identified. Moreover, enzymes involved in amino acid biosynthesis were found upregulated (spots 30 and 38) as well as another enzyme involved in secondary phenylpropanoid metabolism (isoflavone reductase [IFR], spot 28).

Further, a significant protein pattern was found to be particularly induced in cell cultures inoculated with the A. euteiches zoospores inoculums at both early and late inoculation stages, comprising enzymes of carbohydrate metabolism involved in energy-related cellular processes. Located in a specific gel area (32 to $43 \mathrm{kDa}$ molecular weight, $\mathrm{p} I$ range of 6 to 8 ), it revealed inoculation-related induction together with spots 14 to 16 , abundant in close proximity to this pattern. This functional cluster represents spots 12 and 16 (two isoforms of an alcohol dehydrogenase 1), spots 17 and 35 (fructose-bisphosphate aldolase-like protein), spot 18 (glyceraldehyde-3-phosphate dehydrogenase), spot 34 (malate dehydrogenase), and spot 36 (fumarate hydratase 1).

At early cell elicitation stages, clearly fewer proteins are found comparison with early A. euteiches zoospore inoculation stages (Fig. 4A compared with C). The analyses revealed similar induction of protein spots 2 to 6,10 , and 11 that already were found induced at an early A. euteiches inoculation stage, including the superoxide dismutase precursor (spot 6) as putative key enzyme of early defense response, as well as the two VDAC porin-related proteins (spots 10 and 11). Interestingly, the mentioned proteins were also found induced after elicitation with the heat-treated medium. Additional induced proteins of cell elicitation are L-ascorbate peroxidase (spot 39) and a Cat2 catalase (spot 44) involved in detoxification processes of ROS, a 2,4-Dinducible gluthathione $S$-transferase (spot 42), and two enzymes of carbohydrate metabolism (spots 40 and 41). In contrast to an A. euteiches zoospores inoculation, PR proteins as well as proteins associated with secondary phenylpropanoid or phytoalexin metabolism failed to appear consequently in the protein patterns of elicited M. truncatula cell cultures. Moreover, the already described protein cluster involved in carbohydrate metabolism and energy-related cellular processes (spots 12,16 to 18 , and 34 to 36) was continuously absent in all approaches carried out with elicited cell culture tissue.

In gels of mock-inoculated control cultures, two ribosomal proteins (spots M1 and M2) were found induced compared with $A$. euteiches-inoculated cell cultures.

\section{Phosphoproteomic analysis \\ of M. truncatula cell suspension cultures elicited and inoculated with $A$. euteiches using specific antibodies for detection of peptide phosphorylation.}

In order to identify proteins involved in early defenserelated signaling processes after $A$. euteiches inoculation, proteomic analyses combined with subsequent immunoblotting experiments using antibodies targeted against serine-, tyrosine-, and threonine-phosphorylated peptides were performed for an initial timepoint of $1.5 \mathrm{~h}$ post treatments.

Immunoblotted membranes for corresponding gels of $\mathrm{A}$. $\mathrm{eu}$ teiches-inoculated M. truncatula cell cultures (Fig. 5A, anti- phosphoserine, -phosphotyrosine, and -phosphothreonin) and $A$. euteiches-elicited cells (Fig. 5B, anti-phosphoserine) were compared with those of the mock-treated controls (anti-phosphoserine). The membranes for A. euteiches-elicited cultures immunoblotted with anti-phosphoserine covered all labeled spots that appeared also on anti-phosphotyrosine and -phosphothreonine immunoblots of the corresponding cultures; thus, only antiphosphoserine membranes are shown in Figure 5B identifying the three types of phosphorylations-also in the controls.

Obviously, the vast majority of phosphorylated protein spots could be detected in gels of A. euteiches zoospore-inoculated cell cultures: 41 different protein spots (P1 to $\mathrm{P} 41)$ and an additional 6 protein spots that had been already found induced in 2-D gels of A. euteiches-inoculated cells (spots 20,32, and 34 to 37) could be identified to be phosphorylated, representing 35 different $M$. truncatula proteins in total (Table 2). In comparison, analyses of A. euteiches-elicited cell cultures revealed detection of 13 phosphorylated protein spots representing 10 different $M$. truncatula proteins. Moreover, all these proteins were identified as being phosphorylated after A. euteiches inoculation. In both mock-inoculated controls, the same number of phosphorylated proteins was detected in the immunoassays: eight and seven protein spots representing six and five different proteins, respectively.

As can be assumed for peptide phosphorylation events in plant tissue, the vast majority of phosphorylated amino acids were serine residues: 41 of 47 phosphorylated protein spots exhibited phosphorylations of serine (Table 2). Nine serine phosphorylated protein spots also revealed tyrosine phosphorylations and seven were found to be secondary phosphorylated at threonine residues. Only six protein spots revealed specific threonine phosphorylations (Table 2).

\section{Mass spectrometry-based identification}

\section{of proteins detected in phosphoproteomic analyses.}

A phosphoproteomic analysis using tryptic in-gel digestion and mass spectrometry-based protein analysis (MtGI) led to the identification of all phosphorylated proteins detected after A. euteiches inoculation. Again, no significant scores were found in additional sequence blasts performed with the "Aphano DB" EST database (Madoui et al. 2007).

Consistent with the results obtained from the 2-DE analyses, protein phosphorylation in cell cultures after A. euteiches zoospore inoculation appeared to be different from that of A. euteiches-elicited culture tissue in terms of i) the specific detection of phosphorylation events among PR proteins, ii) proteins associated with secondary phenylpropanoid or phytoalexin metabolism, and iii) proteins assigned to carbohydrate metabolism and energy-related cellular processes (Table 2).

Specific phosphorylation of proteins following A. euteiches zoospore inoculation of cell cultures was observed for a PR-10like protein (spot 20) and a class I chitinase (spot 32) representing PR proteins, an NADH-cytochrome b5 reductase-like protein (P13), and three isoforms of an IFR (P15, P40, and P41) as members of secondary phenylpropanoid metabolism, and for several enzymes of carbohydrate metabolism such as alcohol dehydrogenase-like proteins ( $\mathrm{P} 9, \mathrm{P} 17$, and P18), pyruvate dehydrogenase E1 (P14), fructose-bisphosphate aldolase-like protein (P19, P23, and spot 35), glyceraldehyde-3-phophate dehydrogenase (P21 and P22), ENO 2 enolase (P25 to P29), formatetetrahydrofolate ligase (P32), aconitate hydratase (P36), putative mitochondrial ATP synthase (P38), malate dehydrogenase (spot 34 ), and fumarate hydratase 1 (spot 36). Thus, compared with the 2-DE analyses of A. euteiches-inoculated cells, an exceeding number of protein spots related to carbohydrate metabolism was detected specifically phosphorylated after A. euteiches inoculation, located in the already mentioned gel area (32- to 43-kDA 

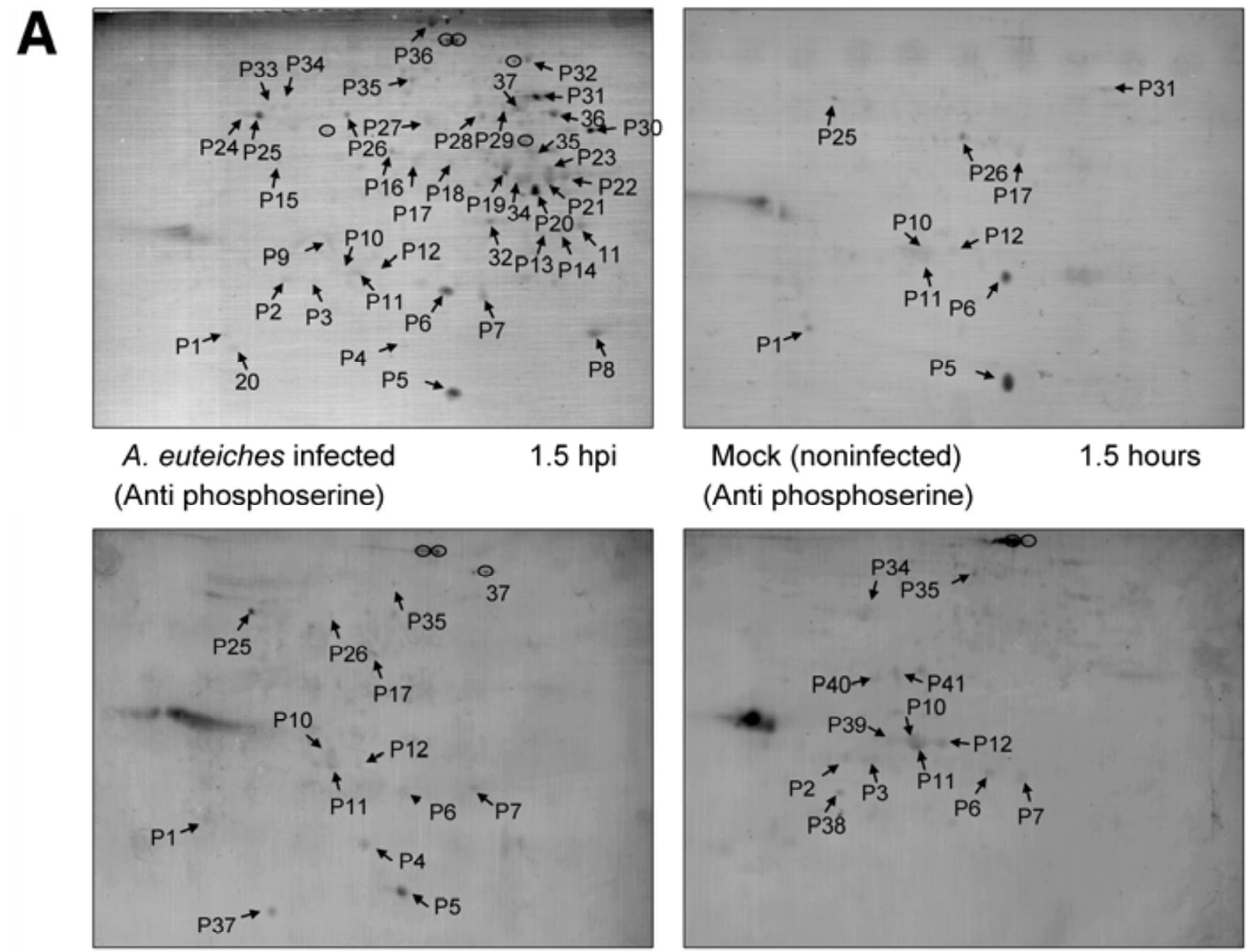

\section{A. euteiches infected (Anti phosphotyrosine) \\ $1.5 \mathrm{hpi}$}
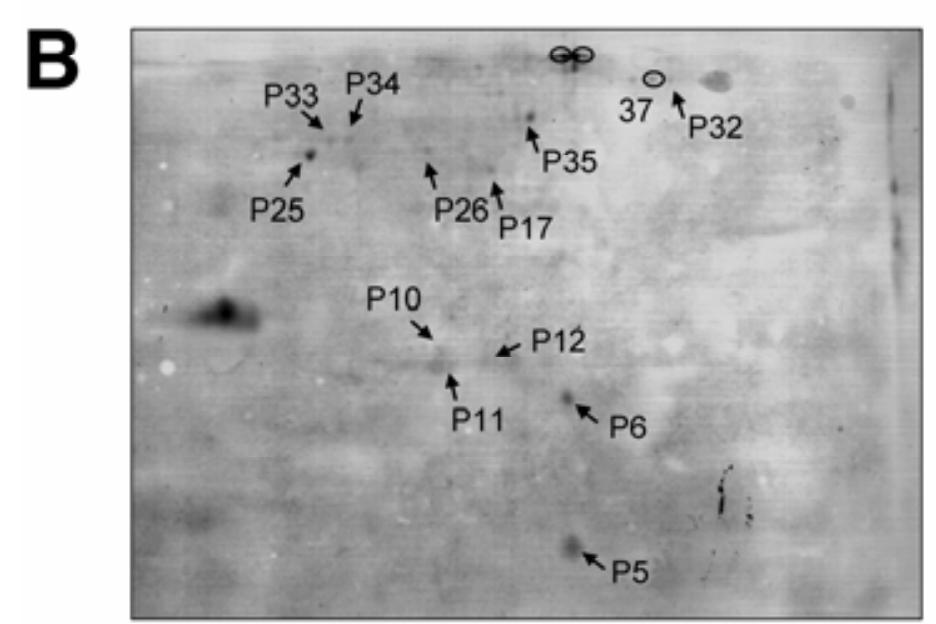

\section{A. euteiches elicited (MPB) 1.5 hours (Anti phosphoserine)}

\section{A. euteiches infected} (Anti phosphothreonine)

$1.5 \mathrm{hpi}$

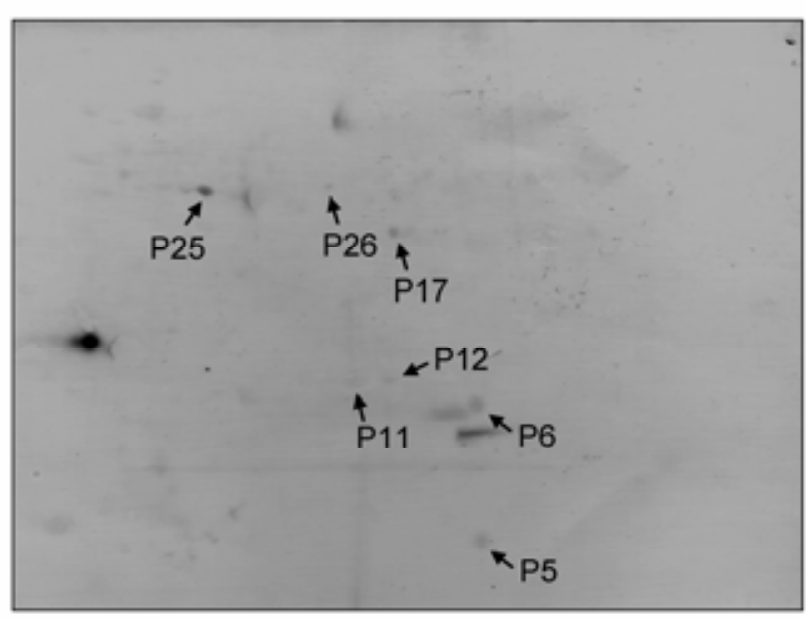

\section{A. euteiches nonelicited 1.5 hours (Anti phosphoserine)}

Fig. 5. Immunoanalysis of two-dimensional (2-D) gels from Aphanomyces euteiches-inoculated and -elicited cell cultures using antibodies against serine, tyrosine, and threonine phosphorylated peptides (1.5 h post treatments). A, Immunoblots of 2-D gels from A. euteiches-inoculated and mock-inoculated (control) cell cultures for anti-phosphoserine, anti-phosphotyrosine, and anti-phosphothreonine. Labeled protein spots identified by mass spectrometry are numbered: P1 to P41. B, Immunoblots of 2-D gels from A. euteiches-elicited and maltose-peptone (MPB) medium (control)-treated cell cultures for antiphosphoserine. Labeled protein spots identified by mass spectrometry are numbered. 
molecular weight, $\mathrm{p} I$ range of 6 to 8 ). Again, this phosphorylation pattern remained continuously absent in A. euteicheselicited cultures as well as in all controls.

In addition, several spots representing the same proteins appeared phosphorylated: the ENO 2 enolase (five isoforms, represented by tentative consensus sequences (TC) 100309 and 105276), GST (four isoforms, represented by TC 94259 and 107452), L-ascorbate peroxidase (three isoforms TC 106425), and alcohol dehydrogenase (three isoforms, TC 103798 and 100664) (Table 2).

\section{DISCUSSION}

In the studies presented here, we expanded the investigations on elicitor-stimulated molecular defense responses to an analysis of inoculation-triggered defense reactions by applying infectious mobile zoospores from the oomycete plant pathogen A. euteiches to $M$. truncatula cell-suspension cultures. This approach allowed a direct comparison of protein patterns induced by $A$. euteiches inoculation with those induced by elicitation. In addition, comparison with protein profiles induced by in planta infections became possible. Although cultured cells may never be representative of all aspects of parasitic interaction, the cell cultures were shown to be competent for perception of the diffusible signals released by $A$. euteiches. Significant decreases in cell viability only occur after inoculation of $M$. truncatula cells with $A$. euteiches zoospores and indicate a fully compatible interaction. Thus, the $M$. truncatula cell-suspension cultures represent a simplified system suitable for monitoring and dissecting molecular events of early and late $\mathrm{A}$. $\mathrm{eu}$ teiches inoculation stages.

\section{M. truncatula cell suspension cultures exhibit responsiveness} for A. euteiches inoculation and elicitation signals.

An oxidative burst assay was applied to prove the responsiveness of the cell cultures for perception of A. euteiches inoculation and elicitation signals. Production of $\mathrm{H}_{2} \mathrm{O}_{2}$ was slightly higher after inoculation than after elicitation but relatively moderate compared with a treatment with invertase. The heat-treated A. euteiches elicitor exhibited induction of approximately $60 \%$ of the $\mathrm{H}_{2} \mathrm{O}_{2}$ maxima of the corresponding nonheated fraction. This indicates a heterogeneous composition of the crude elicitor extract containing heat-stable constituents, putatively cell wall oligomers of the oomycete, as well as heat-sensitive molecules (e.g., proteins that become inactivated by the heat-treatment). Elicitor samples harvested at earlier timepoints (2 to 5 days) did not induce any oxidative burst reaction when applied to the cell cultures. Because A. euteiches cultures reveal a period of rapid increases in fresh weights between days 5 and 8 of culturing, autolysis of the cultures and the release of proteolytic enzymes additionally acting as plant elicitors is highly unlikely. The potential of the elicitor (and even that of the heat-treated elicitor) to induce an oxidative burst that is comparable with the oxidative burst reaction of the zoospore fraction indicates that plant defense suppressors are not abundant in the elicitor fraction.

Microscopic analysis of $A$. euteiches zoospore-treated $M$. truncatula cell cultures revealed a compatible interaction under the conditions used. Therefore, an elaborated method for culturing the plant cells was established that allowed cell-to-cell association with the pathogen but minimized effects of oxygen deficiency. After germination of cysts, hyphae growth was observed to veer toward the plant cells and direct contact between germ tubes and plant cells was achieved. At later inoculation timepoints ( $>2$ dpi), hyphae appeared in intimate contact with the plant cells by forming a cell-to-cell network. These findings correlate with the significant decrease of viable plant cells in the cultures. Because the association during infection requires living host cells to complete the infection process (Kamoun 2006), this association resembles the intercellular hyphae network formed after $A$. euteiches infections in planta, although no appressoria or haustoria formation could be observed in the cultured cells.

However, the microscopic and oxidative burst assays provided the basis for a comprehensive analysis of the molecular events induced by inoculation compared with a sole elicitation under almost uniform and constant experimental standards.

\section{Proteomic analysis reveals induction of distinct defense-associated protein patterns in A. euteiches-elicited and-inoculated M. truncatula cell cultures.}

Although earlier studies on the pathogenic interaction formed between $M$. truncatula and A. euteiches identified a PR-10-like protein group involved in tolerance toward A. euteiches infection (Colditz et al. 2005, 2007), the present proteomic analysis allowed identification of proteins which are induced after inoculation but not after elicitation. Because no matches were found in the "Aphano DB" EST database (Madoui et al. 2007) for any sequence analyzed, all proteins identified were regarded as being of plant origin.

The proteomic differences found suggest distinct molecular defense responses in $M$. truncatula initiated after inoculation with the zoospores compared with an elicitation of the cells. A first hint is given by a significantly increased number of induced proteins after inoculation with the zoospores: whereas 38 proteins were found induced in gels of $A$. euteiches-inoculated cell cultures, only 16 proteins revealed induction after $A$. euteiches elicitation. Especially at later timepoints, protein induction in inoculated cell cultures was clearly enhanced compared with elicited cells (19/6 induced proteins). Furthermore, protein induction in elicited $M$. truncatula cell cultures has a more transient character and appears to be confined to 3 days. Thus, after initial stimulation of defense responses due to elicitation, the cell cultures were not further challenged. By contrast, protein abundances for the induced proteins at later A. euteiches inoculation timepoints ( 2 to $4 \mathrm{dpi}$ ) showed slight but steady increases.

\section{Protein induction at early $A$. euteiches inoculation and elicitation timepoints.}

Qualitative evaluation of protein induction after A. euteiches incubation shows a set of seven proteins (numbers 2 to 6,10 , and 11) to be induced upon both applications (inoculation and elicitation) at early timepoints. These candidates are most likely involved in initial elicitor recognition and oxidative burst reaction. The other proteins (numbers 1, 7, 8, 9, and 12 to 19) were found specifically induced in the zoospore-inoculated cultures. They were abundant already at early timepoints but revealed their induction peaks at later inoculation timepoints and will be discussed below.

The production of ROS represents the major functional element of the oxidative burst reaction involved in primary pathogen defense, membrane restructuring, and defense gene expression as well as programmed cell death and senescence (Jones 2001; Teixeira et al. 2005). A complex antioxidant metabolic system comprising enzymes such as superoxide dismutases (protein 6), ascorbate peroxidases (protein spots 39, P11, P12, and P39), catalases (proteins 44 and P30), various members of GST (proteins 3, 42, P2, P3, P6, and P7, appearing as several isoforms), glutathione reductases (GR; proteins 37 and P30), and glutathione phospholipid hydroperoxide peroxidases (PhGPx; proteins 7 and P4) was found to be induced in the $M$. truncatula cell cultures to maintain cell redox homeostasis and to protect cells against potentially hazardous effects of ROS.

Protein no. 4 reveals similarities to $N$-acylethanolamine (NAE) amidohydralases known as endogenous lipid- and mem- 
brane-bound constituents of plant and animal tissues. In tobacco, they function as endogenous modulators of pathogen elicitor signaling (Tripathy et al. 2003). An elicitor-activated increase of the NAE level induced systemic-acting defense gene expression (e.g., phenylalanine ammonia-lyase [PAL]) within hours after treatment. High-affinity NAE-binding proteins were identified from Arabidopsis thaliana and M. truncatula tissue that were assumed to mediate the NAE-dependent PAL and defense gene activation (Tripathy et al. 2003). Putatively, the protein identified here is involved in a vegetative NAE-signaling pathway participating in elicitor perception and defense gene activation.

Proteins 10 and 11 were identified as voltage-dependent anion channel porins, VDAC1.3 and VDAC1.1. VDAC are generally considered to conduct the major metabolite transport across the mitochondrial outer membrane (OMM) (Heins et al. 1994; Lee et al. 1998; Wandrey et al. 2004). In plants, VDAC might also be located in the boundary membrane of glyoxisomes (Corpas et al. 2000). Analyses of the subcellular localization of Lotus japonicus LjVDAC1.1 and LjVDAC1.3 re- vealed their presence at vesicular and plasma-membrane-associated nonmitochondrial structures (Wandrey et al. 2004). These findings indicate that VDAC might be related to secretory pathways also in vegetative tissues because VDAC fusion proteins were found to be associated to secretory vesicles in animals (Buettner et al. 2000). Interestingly, proteomic studies on isolated symbiosome membranes from legume nodules elucidated accessory involvement of VDAC in symbiotic metabolite exchange between plants and interacting microbes (Wienkoop and Saalbach 2003). Hence, in addition to their ubiquitous targeting to the OMM, a participation of VDAC in plant interactions with microbes and functional relations to the secretome might be possible.

\section{Protein induction \\ at late Aphanomyces euteiches inoculation timepoints.}

Protein induction at late $A$. euteiches inoculation timepoints ( 2 to 4 dpi) is almost entirely confined to $M$. truncatula cell cultures inoculated with zoospores. Here, protein patterns were induced that are specifically related to a sustained defense re-

Table 2. Analysis of the inoculation proteome, elicitation proteome, and phosphoproteome of Medicago truncatula cell suspension cultures inoculated with Aphanomyces euteiches ( 0.25 to 4 days; $1.5 \mathrm{~h}$ ) with protein phosphorylation at serine (ser), tyrosine (tyr), and threonine (threo) residues (1.5 h)

\begin{tabular}{|c|c|c|c|c|c|c|c|c|}
\hline \multirow[b]{2}{*}{ Protein } & \multirow[b]{2}{*}{ TC no. ${ }^{\mathrm{c}}$} & \multirow[b]{2}{*}{ Annot. $^{d}$} & \multirow[b]{2}{*}{ Protein name } & \multirow[b]{2}{*}{$\mathbf{M W} / \mathbf{p} I$} & \multirow[b]{2}{*}{ Cov. $(\%) /$ pep $^{\mathrm{e}}$} & \multicolumn{3}{|c|}{ Phosphorylation ${ }^{a}$} \\
\hline & & & & & & Ser & Tyr & Threo \\
\hline \multicolumn{9}{|c|}{ Inoculated } \\
\hline P1 & 108781 & PO9886 & Small heat-shock protein chloroplast precursor & $18.4 / 4.43$ & $19 / 4$ & + & + & - \\
\hline $\mathrm{P} 2$ & 94259 & O49235 & $\begin{array}{l}\text { 2,4-D inducible glutathione } S \text {-transferase (EC 2.5.1.18 EC } \\
2.5 .1 .18 \text { ) }\end{array}$ & $25.6 / 5.10$ & $28 / 8$ & + & - & + \\
\hline P3 & 94259 & O49235 & 2,4-D inducible glutathione $S$-transferase & $25.6 / 6.24$ & $39 / 10$ & + & _- & + \\
\hline P4 & 94412 & O48646 & $\begin{array}{l}\text { Probable phospholipid hydroperoxide glutathione peroxidase } \\
\text { mitoch. prec. (PHGPx), partial (74\%) }\end{array}$ & $19.3 / 7.37$ & $26 / 7$ & + & - & - \\
\hline P5 & 106697 & BAA12982 & Nucleoside diphosphate kinase I (Pisum) (PNDKN1) & $18.6 / 5.98$ & $20 / 5$ & + & + & - \\
\hline P6 & 94259 & O49235 & 2,4-D inducible glutathione $S$-transferase & $25.6 / 7.30$ & $34 / 9$ & + & + & + \\
\hline P7 & 107452 & Q948X4 & Glutathione $S$-transferase & $24.3 / 8.12$ & $26 / 7$ & + & + & + \\
\hline P8 & 106311 & Q41119 & Cyclophilin (EC 5.2.1.8) & $18.4 / 9.36$ & $34 / 6$ & + & - & - \\
\hline P9 & 103798 & Q9LW35 & Alcohol dehydrogenase-like protein, partial (36\%) & $24.6 / 5.57$ & $34 / 5$ & + & - & - \\
\hline P10 & 106494 & Q9M611 & Soluble inorganic pyrophosphatase, partial (90\%) & $24.7 / 6.23$ & $35 / 8$ & + & + & + \\
\hline P11 & 106425 & A45116 & L-ascorbate peroxidase cytosolic - garden pea & $27.1 / 6.28$ & $40 / 8$ & - & - & + \\
\hline P12 & 106425 & A45116 & L-ascorbate peroxidase cytosolic - garden pea & $27.1 / 6.28$ & $34 / 7$ & - & - & + \\
\hline P13 & 108603 & P83291 & NADH-cytochrome b5 reductase-like protein (B5R) & $34.0 / 8.29$ & $20 / 8$ & + & - & - \\
\hline P14 & 94528 & P52904 & $\begin{array}{l}\text { Pyruvate dehydrogenase E1 component } \beta \text { subunit, mitoch. prec. } \\
\text { (PDHE1-B) }\end{array}$ & $35.1 / 8.32$ & $19 / 5$ & + & - & - \\
\hline P15 & 94281 & Q9LKI6 & Isoflavone reductase (IFR) (2'-hydroxyisoflavone red.) & $35.6 / 5.40$ & $30 / 11$ & + & - & - \\
\hline P16 & 94406 & BAD12188 & 12-oxophytodienoic acid 10,11-reductase (OPR) & $45.5 / 6.08$ & $22 / 7$ & + & - & - \\
\hline P17 & 100664 & P12886 & Alcohol dehydrogenase 1, partial (46\%) (E.C. 1.1.1.1) & $41.1 / 6.25$ & $46 / 7$ & + & + & - \\
\hline P18 & 100663 & P12886 & Alcohol dehydrogenase 1, partial (82\%) (E.C. 1.1.1.1) & $41.1 / 6.33$ & $38 / 6$ & + & _- & - \\
\hline P19 & 106580 & P46257 & Fructose-bisphosphate aldolase, cyt. isozyme 2 & $43.7 / 7.41$ & $31 / 7$ & + & - & - \\
\hline P20 & 100539 & O24076 & Guanine nucleotide-binding protein $\beta$ subunit & $38.2 / 7.21$ & $50 / 15$ & + & _- & - \\
\hline P21 & 106518 & P34922 & Glyceraldehyde-3-phosphate dehydrogenase, cyt. & $39.6 / 7.51$ & $30 / 7$ & + & - & - \\
\hline P22 & 106518 & P34922 & Glyceraldehyde-3-phosphate dehydrogenase, cyt. & $40.0 / 7.55$ & $35 / 8$ & + & - & - \\
\hline P23 & 94614 & Q8W4G8 & Fructose-bisphosphate aldolase-like protein & $41.7 / 7.55$ & $34 / 12$ & + & - & - \\
\hline P24 & 106831 & P29677 & Mitochondrial processing peptidase $\alpha$ subunit & $55.1 / 5.04$ & $19 / 7$ & + & - & - \\
\hline P25 & 100309 & Q6RIB7 & ENO 2 Enolase (E.C. 2.3.1.1.6) & $53.8 / 5.10$ & $22 / 10$ & + & + & - \\
\hline P26 & 100309 & Q6RIB7 & ENO 2 Enolase (E.C. 2.3.1.1.6) & $53.8 / 5.54$ & $41 / 15$ & + & + & - \\
\hline P27 & 100309 & Q6RIB7 & ENO 2 Enolase (E.C. 2.3.1.1.6) & $53.8 / 6.34$ & $37 / 14$ & + & - & - \\
\hline P28 & 105276 & Q7XBE4 & ENO 2 Enolase (E.C. 4.2.1.11) & $52.6 / 8.03$ & $45 / 11$ & + & - & - \\
\hline P29 & 100309 & Q6RIB7 & ENO 2 Enolase (E.C. 2.3.1.1.6) & $54.5 / 8.20$ & $26 / 11$ & + & - & - \\
\hline P30 & 107373 & Q43621 & Glutathione reductase cytosolic (GR) (GRase) & $57.0 / 9.34$ & $19 / 7$ & + & - & - \\
\hline P31 & 100988 & P25890 & Catalase (EC 1.11.1.6 EC 1.11.1.6 EC 1.11.1.6) & $62.9 / 8.51$ & $22 / 12$ & + & - & - \\
\hline P32 & 107891 & A43350 & Formate-tetrahydrofolate ligase (E.C. 6.3.4.3) & $67.9 / 8.25$ & $25 / 15$ & + & - & - \\
\hline P33 & 100696 & Q9LKJ4 & Alanine aminotransferase, partial (71\%) (E.C. 2.2.6.1.2) & $52.7 / 6.03$ & $19 / 6$ & + & - & - \\
\hline \multirow[t]{2}{*}{ P34 } & 100696 & Q9LKJ4 & Alanine aminotransferase, partial (71\%) (E.C. 2.2.6.1.2) & $52.7 / 6.20$ & $23 / 7$ & + & - & + \\
\hline & & & & & & \multicolumn{3}{|c|}{ (continued on next page) } \\
\hline
\end{tabular}

\footnotetext{
${ }^{\text {a }}$ Marked with + after A. euteiches cell inoculation, cell elicitation, and mock inoculation (P1-P41); - = no phosphorylation event detected.

${ }^{\mathrm{b}}$ Protein numbers. Inoc. $=$ proteins phosphorylated in inoculated cells, Iden. $=$ phosphorylated proteins already identified at early and late inoculation stages, Elict. $=$ proteins phosphorylated upon elicitation, Mock $=$ proteins phosphorylated in Mock-inoculated controls, and MPB = proteins phosphorylated in maltose-peptone (MPB)-incubated controls.

${ }^{\mathrm{c}}$ Tentative consensus sequence (TC) or accession number.

${ }^{\mathrm{d}}$ Annotation number.

${ }^{\mathrm{e}}$ Percent covered and peptide number.
} 
sponse. Parallel to a sustained defense response at the protein level in the zoospore-inoculated cells, significantly decreasing rates of viable cells were observed for later inoculation timepoints. As already mentioned, their induction was indicated at early inoculation timepoints via identification of proteins 1,8 , 9, and 12 to 19 that appeared absent in elicited cells.

In A. euteiches-inoculated cell cultures ( 2 to $4 \mathrm{dpi}$ ), proteins from three functional groups were induced: i) PR proteins), ii) proteins associated with secondary phenylpropanoid or phytoalexin metabolism, and iii) proteins assigned to carbohydrate metabolism and energy-related cellular processes. Among the PR proteins, two members of PR10-like proteins (TC 94217 [protein 1] and TC 106355 [protein 20]), one PR-5b thaumatin-like protein (protein 24), and a class I chitinase (protein 32) were found to be induced. These results are coincident with the detected PR protein induction in A. euteiches-inoculated $M$. truncatula roots as reported previously (Colditz et al. 2004, 2005, 2007), indicating similar molecular responses to an A. euteiches inoculation in planta as in the cell cultures. Interestingly, RNA $i$-mediated gene silencing of an MtPr10-1 isoform (TC 109466) (Colditz et al. 2007) revealed the strongest silencing effects at the protein level for these particular two PR-10 forms, TC 94217 and TC 106355. Thaumatin-like PR$5 \mathrm{~b}$ was found with antagonistic induction pattern to PR-10 in the MtPr10 RNA $i$ lines; here, it reveals induction peaks at later inoculation timepoints (protein 24, 3 and 4 dpi) when at least one of the PR10-like proteins (protein 1, TC 94217) is clearly reduced in abundance.

In addition to the PR protein induction, an $\mathrm{R}$ - protein was detected by identifying the R14 protein (TC101874). The $R 14$ gene is a member of a resistance gene cluster in soybean providing resistance to powdery mildew and Phytophthora stem and root rot (Graham et al. 2002). Because the R14 protein was specifically identified to be induced in A. euteiches zoospore-inoculated cell cultures but not in elicited cells, it might be involved in A. euteiches recognition and response, specifically during a physical interaction between both partners. Moreover, the R14 protein was induced at later inoculation timepoints, where an associative network between plant cells and pathogen has been established.

Table 2. (continued from preceding page)

\begin{tabular}{|c|c|c|c|c|c|c|c|c|}
\hline \multirow[b]{2}{*}{ Protein $^{b}$} & \multirow[b]{2}{*}{ TC no. ${ }^{\mathrm{c}}$} & \multirow[b]{2}{*}{ Annot. $^{d}$} & \multirow[b]{2}{*}{ Protein name } & \multirow[b]{2}{*}{$\mathbf{M W} / \mathbf{p} I$} & \multirow[b]{2}{*}{ Cov. $(\%) /$ pep $^{\text {e }}$} & \multicolumn{3}{|c|}{ Phosphorylation $^{\text {a }}$} \\
\hline & & & & & & Ser & Tyr & Threo \\
\hline P35 & 102206 & Q9STH1 & Stress-induced protein sti1-like protein, partial (94\%) & $58.5 / 6.64$ & $20 / 8$ & + & - & + \\
\hline P36 & 94680 & P49608 & Aconitate hydratase (Citrate hydrolyase) & $109.4 / 7.39$ & $23 / 20$ & + & - & - \\
\hline P37 & 100552 & Q8GUR9 & Thioredoxin $\mathrm{h}$ & $12.8 / 5.10$ & $33 / 6$ & + & + & - \\
\hline P38 & 106863 & Q6L460 & Putative mitochondrial ATP synthase & $21.4 / 5.20$ & $42 / 12$ & - & - & + \\
\hline P39 & 106425 & A45116 & L-ascorbate peroxidase cytosolic_-garden pea & $27.1 / 5.52$ & $40 / 8$ & - & - & + \\
\hline P40 & 100786 & Q9SDZ1 & Isoflavone reductase homolog 1 & $33.8 / 5.58$ & $39 / 10$ & - & - & + \\
\hline $\mathrm{P} 41$ & 100786 & Q9SDZ1 & Isoflavone reductase homolog 1 & $33.8 / 6.18$ & $35 / 9$ & - & - & + \\
\hline \multicolumn{9}{|c|}{ Identified } \\
\hline 20 & 106355 & Q8L6K8 & Pprg2 protein/PR-10-like protein & $16.9 / 4.45$ & $32 / 6$ & + & - & - \\
\hline 32 & 106842 & P93327 & Class I chitinase (EC 3.2.1.14) & $35.9 / 7.85$ & $25 / 6$ & + & - & - \\
\hline 34 & 100429 & O48905 & Malate dehydrogenase cytoplasmic & $39.5 / 7.25$ & $24 / 8$ & + & - & - \\
\hline 35 & 94614 & Q8W4G8 & Fructose-bisphosphate aldolase-like protein & $42.7 / 8.34$ & $34 / 8$ & + & - & - \\
\hline 36 & 103200 & P93033 & Fumarate hydratase 1 mitoch. prec. (Fumarase 1) & $56.6 / 8.84$ & $23 / 7$ & + & - & - \\
\hline 37 & 107373 & Q43621 & Glutathione reductase cyt. (GR) (GRase) (GOR2) & $62.0 / 8.51$ & $24 / 8$ & + & - & - \\
\hline \multicolumn{9}{|c|}{ 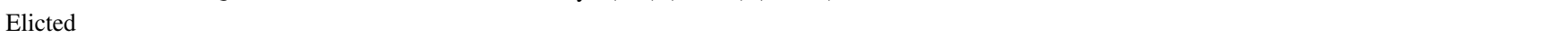 } \\
\hline P5 & 106697 & BAA12982 & Nucleoside diphosphate kinase I (Pisum) (PNDKN1) & $18.6 / 5.98$ & $20 / 5$ & + & + & - \\
\hline P6 & 94259 & O49235 & 2,4-D inducible glutathione $S$-transferase & $25.6 / 7.30$ & $34 / 9$ & + & + & + \\
\hline P10 & 106494 & Q9M611 & Soluble inorganic pyrophosphatase, partial (90\%) & $24.7 / 6.23$ & $35 / 8$ & + & + & + \\
\hline P11 & 106425 & A45116 & L-ascorbate peroxidase cytosolic_-garden pea & $27.1 / 6.28$ & $40 / 8$ & - & - & + \\
\hline $\mathrm{P} 12$ & 106425 & A45116 & L-ascorbate peroxidase cytosolic_-garden pea & $27.1 / 6.28$ & $34 / 7$ & - & - & + \\
\hline P17 & 100664 & P12886 & Alcohol dehydrogenase 1, partial (46\%) (E.C. 1.1.1.1) & $41.1 / 6.25$ & $46 / 7$ & + & + & - \\
\hline P25 & 100309 & Q6RIB7 & ENO 2 Enolase (E.C. 2.3.1.1.6) & $53.8 / 5.10$ & $22 / 10$ & + & + & - \\
\hline P26 & 100309 & Q6RIB7 & ENO 2 Enolase (E.C. 2.3.1.1.6) & $53.8 / 5.54$ & $41 / 15$ & + & + & - \\
\hline P32 & 107891 & A43350 & Formate-tetrahydrofolate ligase (E.C. 6.3.4.3) & $67.9 / 8.25$ & $25 / 15$ & + & - & - \\
\hline P33 & 100696 & Q9LKJ4 & Alanine aminotransferase, partial (71\%) (E.C. 2.2.6.1.2) & $52.7 / 6.03$ & $19 / 6$ & + & - & - \\
\hline P34 & 100696 & Q9LKJ4 & Alanine aminotransferase, partial (71\%) (E.C. 2.2.6.1.2) & $52.7 / 6.20$ & $23 / 7$ & + & - & - \\
\hline P35 & 102206 & Q9STH1 & Stress-induced protein sti1-like protein, partial (94\%) & $58.5 / 6.64$ & $20 / 8$ & + & - & + \\
\hline 37 & 107373 & Q43621 & Glutathione reductase cyt. (GR) (GRase) (GOR2) & $62.0 / 8.51$ & $24 / 8$ & + & - & - \\
\hline \multicolumn{9}{|c|}{$\mathrm{C}$} \\
\hline P1 & 108781 & PO9886 & Small heat-shock protein chloroplast precursor & $18.4 / 4.43$ & $19 / 4$ & + & + & - \\
\hline P5 & 106697 & BAA12982 & Nucleoside diphosphate kinase I (Pisum) (PNDKN1) & $18.6 / 5.98$ & $20 / 5$ & + & + & - \\
\hline P6 & 94259 & O49235 & 2,4-D inducible glutathione $S$-transferase & $25.6 / 7.30$ & $34 / 9$ & + & + & + \\
\hline P10 & 106494 & Q9M611 & Soluble inorganic pyrophosphatase, partial $(90 \%)$ & $24.7 / 6.23$ & $35 / 8$ & + & + & + \\
\hline P11 & 106425 & A45116 & L-ascorbate peroxidase cytosolic_-garden pea & $27.1 / 6.28$ & $40 / 8$ & - & - & + \\
\hline $\mathrm{P} 12$ & 106425 & A45116 & L-ascorbate peroxidase cytosolic_-garden pea & $27.1 / 6.28$ & $34 / 7$ & - & - & + \\
\hline P17 & 100664 & P12886 & Alcohol dehydrogenase 1, partial (46\%) (E.C. 1.1.1.1) & $41.1 / 6.25$ & $46 / 7$ & + & + & - \\
\hline P25 & 100309 & Q6RIB7 & ENO 2 Enolase (E.C. 2.3.1.1.6) & $53.8 / 5.10$ & $22 / 10$ & + & + & - \\
\hline $\mathrm{P} 26$ & 100309 & Q6RIB7 & ENO 2 Enolase (E.C. 2.3.1.1.6) & $53.8 / 5.54$ & $41 / 15$ & + & + & - \\
\hline $\mathrm{P} 31$ & 100988 & $\mathrm{P} 25890$ & Catalase (EC 1.11.1.6 EC 1.11.1.6 EC 1.11.1.6) & $62.9 / 8.51$ & $22 / 12$ & + & - & - \\
\hline \multicolumn{9}{|c|}{ 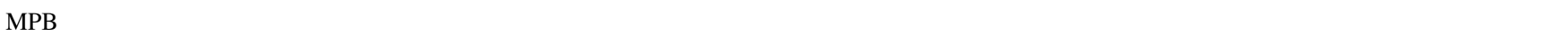 } \\
\hline P5 & 106697 & BAA12982 & Nucleoside diphosphate kinase I (Pisum) (PNDKN1) & $18.6 / 5.98$ & $20 / 5$ & + & + & - \\
\hline P6 & 94259 & $\mathrm{O} 49235$ & 2,4-D inducible glutathione $S$-transferase & $25.6 / 7.30$ & $34 / 9$ & + & + & + \\
\hline P11 & 106425 & A45116 & L-ascorbate peroxidase cytosolic_-garden pea & $27.1 / 6.28$ & $40 / 8$ & - & - & + \\
\hline $\mathrm{P} 12$ & 106425 & A45116 & L-ascorbate peroxidase cytosolic_-garden pea & $27.1 / 6.28$ & $34 / 7$ & - & - & + \\
\hline P17 & 100664 & P12886 & Alcohol dehydrogenase 1, partial (46\%) (E.C. 1.1.1.1) & $41.1 / 6.25$ & $46 / 7$ & + & + & - \\
\hline P25 & 100309 & Q6RIB7 & ENO 2 Enolase (E.C. 2.3.1.1.6) & $53.8 / 5.10$ & $22 / 10$ & + & + & - \\
\hline P26 & 100309 & Q6RIB7 & ENO 2 Enolase (E.C. 2.3.1.1.6) & $53.8 / 5.54$ & $41 / 15$ & + & + & - \\
\hline
\end{tabular}


The B5R (protein 9), naringenin-CHS4 (protein 15), and IFR (protein 28 ) proteins are associated with secondary phenylpropanoid and isoflavonoid metabolism involved in the synthesis of $M$. truncatula pterocarpan phytoalexin medicarpin, the major phytoalexin in Medicago spp. (Higgins 1972). Phenylpropanoid-derived isoflavonoids of legumes generally exhibit a substantial impact on mutualism as well as plant disease or defense, serving as key signaling molecules and antimicrobial compounds of primary defense (Farag et al. 2008). The initial biochemical step of isoflavone synthesis is the derivatization from the flavones naringenin and liquiritigenin to 2-hydroxyisoflavone. This complex reaction is catalyzed by an isoflavone synthase (IFS) and a cytochrome P450 (Farag et al. 2008). The P450 enzymatic activity is enhanced by a specific B5R (protein 9), presumably by acting as an alternative electron donor to NADPH (Winkel-Shirley 2001). In our studies, the B5R was detected to be additionally phosphorylated in $A$. euteiches-inoculated cell cultures (P13), indicating activation of an IFS-cyt. P450-B5R functional multi-enzyme complex, as was proposed by several authors (Burbulis and Winkel-Shirley 1999; Hrazdina and Wagner 1985; Stafford 1974). One step prior, naringenin-CHS4 (protein 15) catalyzes the synthesis of naringenin-chalcone which isomerizes under specific conditions into naringenin. The third enzyme found to be induced is embedded at a later downstream position in the isoflavone/ pterocarpan metabolism; the IFR (protein 28) catalyzes the reaction of 2'-hydroxyformononetin to vestinone (Guo et al. 1994). Coincidently, the IFR appeared to be induced primarily at 3 and 4 dpi whereas the naringenin-CHS4 as well as the B5R revealed induction already at early inoculation timepoints. Because vestinone represents the precursor for medicarpin, it is evident that synthesis of medicarpin is induced in the $M$. truncatula cell cultures after A. euteiches inoculation. Moreover, three different protein spots representing two IFR were found to be specifically phosphorylated after A. euteiches inoculation. By contrast, none of these enzymes were detected with increased abundances or phosphorylation in gels of cell cultures treated with the $A$. euteiches elicitation medium. The absence of protein patterns from the isoflavonoid metabolism in the elicited cell cultures was also reported for the infection proteome of the A. euteiches-tolerant $M$. truncatula line F83.005-9. By contrast, the susceptible F83.005-5 line exhibited significant induction of an isoliquiritigenin 2-O-methyltransferase, IFR1, and a chalcone reductase (Colditz et al. 2005). Thus, induction of medicarpin synthesis in $M$. truncatula cell cultures indicates a fully compatible interaction formed with A. euteiches.

Numerous proteins were identified to be specifically induced in A. euteiches-inoculated cell cultures that are involved in primary metabolic and energy-related cellular processes, including carbohydrate metabolism (glycolysis, tricarboxylic-acid [TCA] cycle, and oxidative phosphorylation) as well as the synthesis of amino acids. In addition, an exceedingly large number of enzymes related to carbohydrate metabolism was detected specifically phosphorylated after A. euteiches inoculation. Among the 10 enzymatic steps in the glycolytic pathway, four were identified as being differentially regulated after A. euteiches inoculation (and additionally phosphorylated $[\mathrm{P}]$ ): fructose-bisphosphate aldolase (proteins 17, 35 [also phosphorylated], P19, and P23), glyceraldehyde-3-phosphate dehydrogenase (proteins 18, P21, and P22), enolase (P25-P29), and malate dehydrogenase (34, also phosphorylated). The mitochondrial pyruvate dehydrogenase complex (detected phosphorylated: P14) catalyzes the key regulatory step of carbohydrate metabolism, the oxidative decarboxylation of pyruvate to acetyl $\mathrm{CoA}, \mathrm{CO}_{2}$, and NADH, linking glycolysis to the TCA cycle. Increased abundances for an alcohol dehydrogenase (16, P17, and P18) is likely the result of increased rates of respiratory $\mathrm{CO}_{2}$ evolution, particularly through glycolysis and oxidative pentose phosphate pathways, as described to occur in plant cell cultures after elicitation with oomycete stimulators (Broeckling et al. 2005; Norman et al. 1994). TCA cycle-induced proteins in A. euteiches-inoculated cell cultures include an aconitate hydratase (P36) converting citrate to isocitrate, a succinyl-CoA ligase (41, specifically induced in elicited cell cultures), fumarase 1 (36, also phosphorylated), and alanine aminotransferase (P33 and P34), which converts pyruvate to alanine. Two enzymes involved in oxidative phosphorylation and ATP synthesis were found with increased phosphorylation after inoculation: the general mitochondrial processing peptidase forming part of complex III in plants (cyt. bc $\mathrm{bc}_{1}$; P24) and a putative mitochondrial ATP synthase (P38).

\section{Induced protein phosphorylation patterns confirm the qualitative molecular defense-response of M. truncatula cell cultures after $A$. euteiches inoculation as detected via 2-DE.}

Phosphorylation and dephosphorylation play a pivotal role in perception and transduction of signals in plant defense responses as documented by treatment of plant cell cultures with (fungal) elicitors (Dietrich et al. 1990; Felix et al. 1991, 1994; Lecourieux-Ouaked et al. 2000; Peck et al. 2001; Viard et al. 1994). However, evaluation of distinct phosphorylation events of not only elicited but also inoculated cell cultures has not yet been described, to our knowledge.

Comparison of protein phosphorylation patterns for A. euteiches-elicited and -inoculated cells revealed 13 proteins being phosphorylated which can be assigned to antioxidative and energy-related processes. Subtraction of seven proteins that showed also phosphorylation after incubation in the absence of A. euteiches leads to five proteins (P32 to P35 and 37) representing a formate-tetrahydrofolate ligase, two alanine aminotransferases, a stress-induced sti1-like protein, and a GR.

Several proteins involved in antioxidant metabolism and cell redox homeostasis were found to be induced at early inoculation timepoints and are also phosphorylated at an initial inoculation stage (1.5 hours postinoculation [hpi]). GST represent the most redundant protein (four isoforms: P2, P3, P6, and P7) of this group. Moreover, one PhGPx (P4) and two GRs (37 and P30) were also detected phosphorylated, next to three isoforms of an L-ascorbate peroxidase (P11, P12, and P39), a catalase (P31), and a thioredoxin $\mathrm{h}$ (P37). Interestingly, proteins that were found to be specifically induced in A. euteiches-inoculated cell cultures at later inoculation timepoints, including i) PR proteins and proteins of ii) secondary phenylpropanoid and iii) carbohydrate metabolism, were already detected phosphorylated at this initial timepoint of $1.5 \mathrm{hpi}$, indicating an early activation of the mentioned defense-related metabolic pathways. Thus, the PR-10-like protein $(20, \mathrm{i})$, a class I chitinase $(32, \mathrm{i}), \mathrm{B} 5 \mathrm{R}$ (P13, ii), IFR (P15, ii), alcohol dehydrogenases (P9, P17, and P18, iii), pyruvate dehydrogenase (P14, iii), fructose-bisphosphate aldolases (P19, P23, and 35, iii), glyceraldehydes-3-phosphate dehydrogenases (P21 and P22, iii), a mitochondrial processing peptidase (P24, iii), enolase 2 (P25 to P29, iii), alanine aminotransferases (P33 and P34, iii), citrate hydrolase (P36, iii), ATP synthase (P38, iii), and a fumarase $(36$, iii) were identified as being phosphorylated.

\section{Modulation of carbon metabolism-an outlook.}

The protein induction and phosphorylation profiles of $\mathrm{A}$. $\mathrm{eu}$ teiches zoospore-inoculated cell cultures indicate the particular and substantial activation of proteins involved in carbohydrate metabolism (20 enzymes among the related pathways). One aspect of this altered metabolic setup might be a pathogen- 
induced reprogramming of cellular carbohydrate metabolism toward the synthesis of carbon sources required by the pathogen; another is the activation of secondary isoflavone metabolism that requires altered primary metabolism.

Referring to the latter aspect, constitutively accumulated glucosides are generally regarded as stable, soluble storage forms of isoflavanoids typically localized in the cell's vacuole (Mackenbrock and Barz 1991). Simultaneous accumulation of proteins from carbohydrate and phenylpropanoid metabolism is supported by an earlier study for an A. euteiches-tolerant $M$. truncatula line, where five members of carbohydrate metabolism were induced together with enzymes of the phenylpropanoid metabolism (Colditz et al. 2005). Thus, induction of both mentioned enzymatic classes maintains marker character for an established and sustained $A$. euteiches infection in $M$. truncatula.

Very recently, Farag and associates (2008) elucidated novel pathways in phenylpropanoid and isoflavanoid biosynthesis of elicitor-specific responses in $M$. truncatula cell cultures; according to the elicitor applied, three isoflavones (afrormosin, alfalone, and irisolidone) were identified for the first time in $M$. truncatula. The biosynthetic origin of these compounds is still a matter of uncertainty (Deavours et al. 2006); pulse labeling studies using exogenous substances now suggested naringenin, precursor for 5-hydroxyisoflavones in legumes, as point of origin (Farag et al. 2008). Occurrence of the CHS4 indicates synthesis of naringenin in A. euteiches-inoculated cell cultures. However, in response to fungal yeast elicitor, the phytoalexin end product medicarpin is mainly increased in M. truncatula cell cultures instead of the newly identified isoflavones (Farag et al. 2008). Our results suggest a coincident biosynthesis of medicarpin in the cell cultures after A. euteiches inoculation, because the inoculation-induced IFR is embedded at a later downstream position in the pterocarpan metabolism leading to synthesis of vestinone, the precursor for medicarpin. Further studies may elucidate whether the mentioned alternative pathways in isoflavonoid biosynthesis are also activated in A. euteiches-inoculated M. truncatula cell cultures.

\section{MATERIALS AND METHODS}

Cell cultures and inoculation with $A$. euteiches.

M. truncatula ('Jemalong A17') cell suspension cultures were obtained by transferring sterile root explants of 1-weekold seedlings on sterile Murashige and Skoog (MS) medium (Murashige and Skoog 1962) supplemented with the phytohormones 2,4-dichlorophenoxyacetic acid (1 mg liter $\left.{ }^{-1}\right)$ and kinetin $\left(0.1 \mathrm{mg} \mathrm{liter}^{-1}\right)$, as described previously by Baier and associates (1999) and Scheidle and associates (2005). During 8 weeks, growth of callus tissue was induced and non-necrotic calli were subcultivated to obtain callus cell cultures of root tissue. For establishment of M. truncatula cell suspension cultures, small amounts of callus tissue were transferred into liquid MS medium. Cell cultures were kept at $25^{\circ} \mathrm{C}$ in the dark while shaking at $130 \mathrm{rpm}$. Cell cultures consisting of single cells and small cell aggregates were used for subcultivation, which was carried out regularly at intervals of 8 to 10 days into $15 \mathrm{ml}$ of fresh MS medium in 125-ml culture flasks (Schott Duran Group, Mainz, Germany). Inoculation experiments were performed 2 to 3 days after cell transfer to fresh medium.

Exposure to A. euteiches (Drechsler), strain ATCC 201684 (kindly provided by S. Rosendahl, Department of Mycology, Botanical Institute, University of Copenhagen, Denmark), was carried out by prudently adding $1 \mathrm{ml}$ of A. euteiches zoospores in lake water (250,000 zoospores per culture flask) or a crude A. euteiches elicitor obtained from culture medium (MPB: 3\% [wt/vol] maltose and $1 \%$ [wt/vol] peptone), wherein the oomycete was cultured for 10 days. Therefore, 10 agar plugs $\left(1 \mathrm{~cm}^{2}\right)$ were cut out from $A$. euteiches vegetative mycelium growing on corn meal agar plates and were transferred to $20 \mathrm{ml}$ of autoclaved MPB. Culture flasks were incubated for 10 days at $20^{\circ} \mathrm{C}$ in the dark without agitation. To initiate the release of zoospores, the MPB was removed and the mycelia were washed with autoclaved lake water taken from a lake in the royal gardens of Herrenhausen, Hannover, Germany (Colditz et al. 2004, 2005; Nyamsuren et al. 2003). The remaining MPB medium was filtered using 595 1/2 S \& S folded filters (Schleicher \& Schuell, Dassel, Germany) to remove mycelia and the filtrate was subsequently used for elicitation of cell cultures as mentioned above. In further experiments, $1 \mathrm{ml}$ of heat-treated MPB (boiled for 10 min after filtration) was added to $M$. truncatula cell cultures. Control root cultures were mock inoculated with the same volume of autoclaved lake water or culture medium (MPB).

After inoculation with the zoospore inoculum, cell cultures were allowed to stand for $1.5 \mathrm{~h}$ in the dark in order to enable movement of zoospores toward the plant cells. Cell cultures were subsequently gently pivoted on a swiveling table for 3.5 hours in the dark in order to initiate encysting of spores and to minimize effects of oxygen deficiency of plant cells. Afterward, the cultures were replaced on the culture shaker in the dark.

Biological samples of four different experiments were harvested from independent culture flasks for both control and $A$. euteiches-treated cell cultures at different timepoints: $0.25,1$, 2,3 , and 4 days. For the analysis of protein phosphorylation, additional samples were collected at $1.5 \mathrm{~h}$. Therefore, separated culture flasks were transferred to the shaker $30 \mathrm{~min}$ after inoculation. For harvesting, plant cells were extracted from the cell culture medium, washed briefly with protein extraction buffer, and transferred to liquid nitrogen for further molecular analyses.

\section{A. euteiches growth curve determination.}

For determination of A. euteiches mycelium growth in liquidgrown MPB cultures, fresh weights of 10 independent cultures were measured for 10 days at 24-h intervals and fresh weights of the initial inoculum (mean of 10 agar plugs $\left[10 \times 1 \mathrm{~cm}^{2}\right]$ in $20 \mathrm{ml}$ of MPB) were subtracted to obtain a growth curve. Culture flasks were incubated at $20^{\circ} \mathrm{C}$ in the dark without agitation.

\section{Determination of $M$. truncatula cell viability via the trypan blue exclusion test.}

For assessment of $M$. truncatula cell viability in the cultures inoculated as described above, the trypan blue (TB) exclusion assay was carried out following a modified protocol for Medicago cell-suspension cultures (Steward et al. 1999). Therefore, a 300- $\mu$ l aliquot of fresh cells of each treatment was diluted with the same volume of culture medium to avoid osmotic stress and stained with $200 \mu \mathrm{l}$ of a $0.4 \%$ (wt/vol) TB aqueous solution for $30 \mathrm{~min}$. The cells were rinsed two times with 300 $\mu \mathrm{l}$ of culture medium. Cell viability expressed as a percentage of living cells was calculated by microscopic evaluation of 500 cells on each slide (Nikon Eclipse 80i). Cells were counted as alive when cytoplasm was clear (not TB stained). Conversely, cells that had incorporated the TB dye were counted as dead. This assay was carried out for each culture and treatment for 10 days at $24-\mathrm{h}$ intervals.

\section{Oxidative burst measurements.}

Oxidative burst measurements were performed using the $\mathrm{H}_{2} \mathrm{O}_{2}$-dependent chemiluminescence assay according to Warm 
and Laties (1982). Therefore, $2 \mathrm{~g}$ of cells was resuspended in $8.5 \mathrm{ml}$ of MS medium for $3 \mathrm{~h}$. Then, cell cultures were subjected to different experimental treatments: yeast invertase (Sigma-Aldrich, Seelze, Germany) at $50 \mu \mathrm{g} \mathrm{ml} \mathrm{m}^{-1}$ as positive control, sterile lake water or culture medium (MPB) as negative controls, and A. euteiches zoospores in lake water $(125,000$ zoospores/culture) and A. euteiches-filtered culture media as described above. All fractions were added in equal volumes of $500 \mu \mathrm{l}$ to the cell cultures, maintaining equal ratio of inoculums to cells as used for the proteomic analyses. Subsequently, oxidative burst measurements were started by transferring $200 \mu \mathrm{l}$ of suspension-cultured cells to $700 \mu \mathrm{l}$ of $50 \mathrm{mM}$ phosphate buffer (pH 7.9) and $100 \mu \mathrm{l}$ of $1.2 \mathrm{mM}$ luminol (Sigma-Aldrich). Chemiluminescence assay was initiated by adding $100 \mu \mathrm{l}$ of potassium-hexacyanate (Fluka, Seelze, Germany). Luminescence was determined with a Sirius luminometer (Berthold Technologies, Bad Wildbach, Germany).

\section{Microscopic analysis of $A$. euteiches inoculation.}

For identification of $A$. euteiches structures in zoosporeinoculated $M$. truncatula cell cultures, microscopic studies were carried out with a Nikon Eclipse 80i microscope combined with a Nikon Digital-Sight DS-2MV digital camera (Nikon, Düsseldorf, Germany).

\section{Phenol extraction of proteins.}

Phenol extraction of total protein from the cells was carried out as described previously (Colditz et al. 2004, 2005). For IEF, $1 \mathrm{mg}$ of protein was diluted with $350 \mu \mathrm{l}$ of rehydration buffer, consisting of $8 \mathrm{M}$ urea, 2\% (wt/vol) CHAPS, $100 \mathrm{mM}$ dithiothreitol, $0.5 \%$ (vol/vol) IPG buffer for correspondent $\mathrm{p} I$ range $(\mathrm{pH}$ 3-10 nonlinear [NL]; Amersham Pharmacia Biotech, Uppsala, Sweden), and a trace of bromphenol blue.

\section{2-DE.}

2-DE was performed for four independent biological experiments at each mentioned timepoint of harvesting, by combining IEF ( $\mathrm{p} I$ 3-10 NL) using an IPGphor system (Amersham Pharmacia Biotech) with a sodium dodecyl sulfate-tricine gel electrophoresis (Protean II XL, 20 by $20 \mathrm{~cm}$; BioRad, Richmond, CA, U.S.A.) as already described (Colditz et al. 2005). Gels were stained with $0.1 \%$ (wt/vol) Coomassie Brilliant Blue (BioRad) overnight and scanned on a UMAX Power Look III Scanner (UMAX Technologies, Fremont, CA, U.S.A.).

For analysis of in-gel protein abundance, each gel prepared was additionally scanned on a Fujifilm FLA-3000 Fluorescence Laser Imager (Fujifilm Medical Systems USA, Stamford, CT, U.S.A.). The relative spot intensities of selected proteins were measured as light absorption units (internal densitometric unit) by using the AIDA Image Analyser (v3.20) evaluation software (Raytest USA, Wilmington, NC, U.S.A.). Therefore, nearby background absorption values were subtracted. For each protein spot analyzed, the corresponding absorption units of four different experiments were measured and averaged. The absorption coefficient was determined for each selected protein spot by comparison of the corresponding in-gel intensities between gels of $A$. euteiches-inoculated cells and gels of controls. These coefficients are displayed as a protein induction index in Table 1.

\section{Immunoblotting experiments.}

For immunoblotting experiments, gels were blotted onto Immobilon-polyvinylidene fluoride membranes (Millipore, Schwalbach/Ts., Germany) in transfer buffer (20 mM Tris base, $20 \%$ [vol/vol] methanol, and $150 \mathrm{mM}$ glycine). Blots were incubated overnight with antibodies directed against phosphorylated serine (Monoclonal Anti-Phosphoserine clone PSR-45; Sigma-Aldrich), tyrosine (Monoclonal Anti-Phosphotyrosine clone PT-66; Sigma-Aldrich), or threonine (Monoclonal Anti-Phosphothreonine clone PTR-8; Sigma-Aldrich) amino acid residues in incubation buffer $(100 \mathrm{mM}$ Tris- $\mathrm{HCl}$ [pH 7.4], 0.1\% Tween 20, and $150 \mathrm{mM} \mathrm{NaCl}$ ). Immune-positive protein spots were stained using the Vectastain ABC-Kit (Vector Laboratories/Axxora, Lörrach, Germany) according to the manufacturer's protocol.

\section{Tryptic in-gel digestion of protein spots, MALDI-TOF/ mass spectrometry-based protein identification.}

For tryptic digestion, protein spots of interest were excised manually from the gels. In-gel digestion with trypsin (Sequencing Grade Modified trypsin; Promega Corp., Madison, WI, U.S.A.) was carried out for $24 \mathrm{~h}$ at $37^{\circ} \mathrm{C}$. Mass spectrometry measurements were performed at an Ultraflex MALDITOF mass spectrometer (Bruker Daltonics, Bremen, Germany) as described previously (Colditz et al. 2007).

\section{Protein annotation.}

PMF obtained in Mascot database were further analyzed using the M. truncatula EST database (MtGI; The Institute for Genome Research, Rockville, MD, U.S.A.). In case of successful sequence matching in MtGI, sequences were verified by performing BlastP protein annotation of the in silico translation products at the United States National Center for Biotechnology Information. Theoretical peptide mass and $\mathrm{p} I$ of the polypeptides were evaluated at EXPASy for final confirmation according to their positions in the 2-DE gel map. Additionally, blast analysis of all sequences to the "Aphano DB" EST database (Madoui et al. 2007) was carried out.

\section{ACKNOWLEDGMENTS}

We thank N. Küpper, University of Bielefeld, Department 7, Proteome and Metabolome research, for her assistance performing the MALDITOFmass spectrometry and database analysis. Further, we thank U. Schmitz, Leibniz University of Hannover, Institute for Plant Genetics, Dept. III, Plant Molecular Biology, for helpful discussions and for proofreading the manuscript. The Deutsche Forschungsgemeinschaft supported this work.

\section{LITERATURE CITED}

Baier, R., Schiene, K., Kohring, B. Flaschel, E., and Niehaus, K. 1999. Alfalfa and tobacco cells react differently to chitin oligosaccharides and Sinorhizobium meliloti nodulation factors. Planta 210:157-164.

Basse, C. W., Bock, K., and Boller, T. 1992. Elicitors and suppressors of the defense response in tomato cells-purification and characterization of glycopeptide elicitors and glycan suppressors generated by enzymatic cleavage of yeast invertase. J. Biol. Chem. 267:10258-10265.

Batz, O., Logemann, E., Reinold, S., and Hahlbrock, K. 1998. Extensive reprogramming of primary and secondary metabolism by fungal elicitor or infection in parsley cells. Biol. Chem. 379:1127-1135.

Birch, P. R. J., Rehmany, A. P., Pritchard, L., Kamoun, S., and Beynon, J. L. 2006. Trafficking arms: Oomycete effectors enter host plant cells. Trends Microbiol. 14:8-11.

Broeckling, C. D., Huhman, D. V., Farag, M. A., Smith, J. T., May, G. D. Mendes, P., Dixon, R. A., and Sumner, L. W. 2005. Metabolomic profiling of Medicago truncatula cell cultures reveals the effects of biotic and abiotic elicitors on metabolism. J. Exp. Bot. 56:323-336.

Buettner, R., Papoutsoglou, G., Scemes, E., Spray, D. C., and Dermietzel, R. 2000. Evidence for secretory pathway localization of voltage-dependent anion channel isoform. Proc. Natl. Acad. Sci. U.S.A. 97:32013206.

Burbulis, I. E., and Winkel-Shirley, B. 1999. Interactions among enzymes of the Arabidopsis flavanoid biosynthetic pathway. Proc. Natl. Acad. Sci. U.S.A. 96:12929-12934

Colditz, F., Nyamsuren, O., Niehaus, K., Eubel, H., Braun, H.-P., and Krajinski, F. 2004. Proteomic approach: Identification of Medicago truncatula proteins induced in roots after infection with the pathogenic oomycete Aphanomyces euteiches. Plant Mol. Biol. 55:109-120. 
Colditz, F., Braun, H.-P., Jacquet, C., Niehaus, K., and Krajinksi, F. 2005. Proteomic profiling unravels insights into the molecular background underlying increased Aphanomyces euteiches-tolerance of Medicago truncatula. Plant Mol. Biol. 59:387-406.

Colditz, F., Niehaus, K., and Krajinski, F. 2007. Silencing of PR-10-like proteins in Medicago truncatula results in an antagonistic induction of other PR proteins and in an increased tolerance upon infection with the oomycete Aphanomyces euteiches. Planta 226:57-71.

Corpas, F. J., Sandalio, L. M., Brown, M. J., del Rio, L. A., and Trelease, R. N. 2000. Identification of porin-like polypeptide(s) in the boundary membrane of oilseed glyxosomes. Plant Cell Physiol. 41:12181228 .

Deavours, B. E., Liu, C. J., Naoumkina, M. A., Tang, Y., Farag, M. A., Sumner, L. W., Noel, J. P., and Dixon, R. A. 2006. Functional analysis of members of the isoflavone and isoflavone O-methyltransferase enzyme families from the model legume Medicago truncatula. Plant Mol. Biol. 62:715-733.

Dietrich, A., Mayer, J. E., and Hahlbrock, K. 1990. Fungal elicitor triggers rapid, transient, and specific protein phosphorylation in parsley cell suspension cultures. J. Biol. Chem. 265:6360-6365.

Dixon, R. A., and Harrison, M. J. 1994. Early events in the activation of plant defense responses. Annu. Rev. Phytopathol. 32:479-501.

Farag, M. A., Huhman, D. V., Dixon, R. A., and Sumner, L. W. 2008. Metabolomics reveals novel pathways and differential mechanistic and elicitor-specific responses in phenylpropanoid and isoflavanoid biosynthesis in Medicago truncatula cell cultures. Plant Physiol. 146:387-402.

Felix, G., Grosskopf, D. G., Regenass, M., and Boller, T. 1991. Rapid changes of protein phosphorylation are involved in transduction of the elicitor signal in plant cells. Proc. Natl. Acad. Sci. U.S.A. 88:88318834.

Felix, G., Regenass, M., Spanu, P., and Boller, T. 1994. The protein phoshatase inhibitor calyculin A mimics elicitor action in plant cells and induced rapid hyperphosphorylation of specific protein as revealed by pulse labeling with [32P] phosphate. Proc. Natl. Acad. Sci. U.S.A. 91:952-956.

Felix, G., Duran, J. D., Volko, S., and Boller, T. 1999. Plants have a sensitive perception system fort he most conserved domain of bacterial flagellin. Plant J. 18:265-276.

Gaulin, E., Dramé, N., Lafitte, C., Torto-Alalibo, T., Martinez, Y. Ameline-Torregrosa, C., Khatib, M., Mazarguil, H., Villalba-Mateos, F., Kamoun, S., Mazars, C., Dumas, B., Bottin, A., Esquerré-Tugayé, M.T., and Rickauer, M. 2006. Cellulose binding domains of a Phytophthora cell wall protein are novel pathogen-associated molecular patterns. Plant Cell 18:1766-1777.

Gaulin, E., Jacquet, C., Bottin, A., and Dumas, B. 2007. Root rot disease of legumes caused by Aphanomyces euteiches. Mol. Plant Pathol. 8:539-548.

Graham, M. A., Marek, L. F., and Shoemaker, R. C. 2002. Organization, expression and evolution of a disease resistance gene cluster in soybean. Genetics 162:1961-1977.

Grosskopf, D. G., Felix, G., and Boller, T. 1990. K-252a inhibits the response of tomato cells to fungal elicitors in vivo and their microsomal protein kinase in vitro. FEBS (Fed. Eur. Biochem. Soc.) Lett. 275:177180

Guo, L., Dixon, R. A., and Paiva, N. L. 1994. Conversion of vestinone to medicarpin in alfalfa (Medicago sativa $\mathrm{L}$.) is catalyzed by two independent enzymes. J. Biol. Chem. 269:22372-22378.

Hagedorn, D. J. 1989. Aphanomyces root rot. Pages 25-28 in: Compendium of Pea Diseases. D. J. Hagedorn, ed. American Phytopathology Society Press, St. Paul, MN, U.S.A.

Halim, V. A., Hunger, A., Macioszek, V., Landgraf, P., Nürnberger, T., Scheel, D., and Rosahl, S. 2004. The oligopeptide elicitor Pep-13 induces salicylic acid-dependent and -independent defence reactions in potato. Physiol. Mol. Plant Pathol. 64:311-318.

Hammond-Kosack, K. E., and Jones, J. D. G. 1996. Resistance gene-dependent plant defense responses. Plant Cell 8:1773-1791.

Heins, L., Mentzel, H., Schmid, A., Benz, R., and Schmitz, U. K. 1994 Biochemical, molecular, and functional characterization of porin isoforms from potato mitochondria. J. Biol. Chem. 42:26402-26410.

Higgins, V. J. 1972. Role of phytoalexin medicarpin in 3 leaf spot diseases of alfalfa. Physiol. Plant Pathol. 2:289-300.

Hrazdina, G., and Wagner, G. J. 1985. Metabolic pathways as enzyme complexes: Evidence for the synthesis of phenylpropanoids and flavonoids on membrane associated enzyme complexes. Arch. Biochem. Biophys. 237:88-100.

Imin, N., De Jong, F., Mathesius, U., van Noorden, G., Saeed, N. A., Wang, X.-D., Rose, R. J., and Rolfe, B. G. 2004. Proteome reference maps of Medicago truncatula embryonic cell cultures generated from single protoplasts. Proteomics 4:1883-1896.
Jones, A. M. 2001. Programmed cell death in development and defense. Plant Physiol. 125:94-97.

Kamoun, S. 2006. A catalogue of the effector secretome of plant pathogenic oomycetes. Annu. Rev. Phytopathol. 44:2.1-2.20.

Lecourieux-Ouaked, F., Pugin, A., and Lebrun-Garcia, A. 2000. Phosphoproteins involved in the signal transduction of cryptogein, an elicitor of defense reactions in tobacco. Mol. Plant-Microbe Interact. 13:821-829.

Lee, A. C., Xu, X., Blachly-Dyson, E., Forte, M., and Colombini, M. 1998. The role of yeast VDAC genes on the permeability of the mitochondrial outer membrane. J. Membr. Biol. 161:173-181.

Lei, Z., Elmer, A. M., Watson, B. S., Dixon, R. A., Mendres, P. J., and Sumner, L. W. 2005. A two-dimensional electrophoresis proteomic reference map and systematic identification of 1367 proteins from a cell suspension culture of the model legume Medicago truncatula. Mol. Cell. Proteom. 4:1812-1825.

Levenfors, J. P., Wikström, M., Persson, L., and Gerhardson, B. 2003. Pathogenicity of Aphanomyces spp. from different leguminous crops in Sweden. Eur. J. Plant Pathol. 109:535-543.

Mackenbrock, U., and Barz, W. 1991. Elicitor-induced formation of pterocarpan phytoalexins in chickpea (Cicer arietinum L.) cell suspension cultures from constitutive isoflavone conjugates upon inhibition o phenylalanine ammonia lyase. Z. Naturforsch. C: Biosci. 46:4350 .

Madoui, M.-A., Gaulin, E., Mathé, C., San Clemente, H., Couloux, A. Wincker, P., and Dumas, B. 2007. AphanoDB: A genomic resource for Aphanomyces pathogens. BioMed. Cent. Genomics 8:471.

Murashige, T., and Skoog, F. 1962. A revised medium for rapid growth and bioassays with tobacco tissue cultures. Physiol. Plant 15:473-497.

Norman, E. G., Walton, A. B., and Turpin, D. H. 1994. Immediate activation of respiration in Petroselinum crispum L. in response to the Phytophthora megasperma f. sp. glycinea elicitor. Plant Physiol. 106:15411546.

Nürnberger, T., Brunner, F., Kemmerling, B., and Piater, L. 2004. Innate immunity in plants and animals: Striking similarities and obvious differences. Immunol. Rev. 198:249-266.

Nyamsuren, O., Colditz, F., Rosendahl, S., Tamasloukht, M., Bekel, T., Meyer, F., Küster, H., Franken, P., and Krajinski, F. 2003. Transcriptional profiling of Medicago truncatula roots after infection with Aphanomyces euteiches (oomycota) identifies novel genes upregulated during this pathogenic interaction. Physiol. Mol. Plant Pathol. 63:17-26.

Peck, S. C., Nühse, T. S., Hess, D., Iglesias, A., Meins, F., and Boller, T. 2001. Directed proteomics identifies a plant-specific protein rapidly phosphorylated in response to bacterial and fungal elicitors. Plant Cell 13:1467-1475.

Ren, Y. Y., and West, C. A. 1992. Elicitation of diterpene biosynthesis in rice (Oryza sativa L.) by chitin. Plant Physiol. 99:1169-1178.

Scheidle, H., Groß, A., and Niehaus, K. 2005. The lipid A substructure of the Sinorhizobium meliloti lipopolysaccharides is sufficient to suppress the oxidative burst in host plants. New Phytol. 165:559-566.

Sharp, J. K., McNeil, M., and Albersheim, P. 1984. The primary structures of one elicitor-active and seven elicitor-inactive hexa( $\beta$-D-glucopyranosyl)-D-glucitols isolated from the mycelial walls of Phytophthora megasperma var. sojae. J. Biol. Chem. 259:11321-11336.

Stafford, H. A. 1974. Possible multi-enzyme complexes regulating the formation of $\mathrm{C}_{6}-\mathrm{C}_{3}$ phenolic compounds and lignins in higher plants. Recent. Adv. Phytochem. 8:53-79.

Steward, N., Martin, R., Engasser, J. M., and Georgen, J. L. 1999. A new methodology for plant cell viability assessment using intracellular esterase activity. Plant Cell Rep. 19:171-176.

Suzuki, K., Fukada, Y., and Shinshi, H. 1995. Studies on elicitor-signal transduction leading to differential expression of defense genes in cultured tobacco cells. Plant Cell Physiol. 36:281-289.

Suzuki, K., Yano, A., and Shinshi, H. 1999. Slow and prolonged activation of the p47 protein kinase during hypersensitive cell death in a culture of tobacco cells. Plant Physiol. 119:1465-1472.

Teixeira, F. K., Menezes-Benavente, L., Costa Galvão, V., and MargisPinheiro, M. 2005. Multigene families encode the major enzymes of antioxidant metabolism in Eucalyptus grandis L. Genet. Mol. Biol. 28 (Suppl.):529-538

Tellström, V., Usadel, B., Thimm, O., Stitt, M., Küster, H., and Niehaus, K. 2007. The lipopolysaccharide of Sinorhizobium meliloti suppresses defense-associated gene expression in cell cultures of the host plant Medicago truncatula. Plant Physiol. 143:1-13.

Tripathy, S., Kleppinger-Sparace, K., Dixon, R. A., and Chapman, K. D. 2003. N-Acylethanolamine signaling in tobacco is mediated by membrane-associated, high-affinity binding protein. Plant Physiol. 131:1781-1791

Viard, M.-P., Martin, F., Pugin, A., Ricci, P., and Blein, J.-P. 1994. Protein 
phosphorylation is induced in tobacco cells by the elicitor cryptogein. Plant Physiol. 104:1245-1249.

Wandrey, M., Trevaskis, B., Brewin, N., and Udvardi, M. K. 2004. Molecular and cell biology of a family of voltage-dependent anion channel porins in Lotus japonicus. Plant Physiol. 134:182-193.

Warm, E., and Laties, G. G. 1982. Quantification of hydrogen peroxide in plant extracts by the chemiluminescence reaction with luminol. Phytochemistry 21:827-831.

Watson, B. S., Asirvatham, V. S., Wang, L., and Sumner, L. W. 2003. Mapping the proteome of barrel medic. Plant Physiol. 131:1104-1123.

Wienkoop, S., and Saalbach, G. 2003. Proteome analysis: Novel proteins identified at the peribacteroid membrane from Lotus japonicus root nodules. Plant Physiol. 131:1080-1090.

Winkel-Shirley, B. 2001. Flavanoid biosynthesis. A colorful model for genetics, biochemistry, cell biology, and biotechnology. Plant Physiol. 126:485-493.

Zhang, S., Liu, Y., and Klessig, D. F. 2000. Multiple levels of tobacco WIPK activation during the induction of cell death by fungal elicitins. Plant J. 23:339-347.

\section{AUTHOR-RECOMMENDED INTERNET RESOURCES}

National Center for Biotechnology Information: www.ncbi.nlm.nih.gov/BLAST

ExPASy proteomics server: www.expasy.org/tools/pi_tool

AphanoDB (a databank for Aphanomyces EST):

www.polebio.scsv.ups-tlse.fr/aphano/ 